DOI: http://dx.doi.org/10.21276/ap.2020.9.2.7

Annals of Phytomedicine: An International Journal http://www.ukaazpublications.com/publications/index.php

\title{
Spices boosting immunity in COVID-19
}

\author{
Santwana Palai*, Manaswini Dehuri* and Ritun Patra** \\ Department of Veterinary Pharmacology and Toxicology, College of Veterinary Science and Animal Husbandry, OUAT, Bhubaneswar-751003, \\ Odisha, India \\ *Department of Veterinary Parasitology, College of Veterinary Science and Animal Husbandry, OUAT, Bhubaneswar-751003, Odisha, India \\ **Department of Veterinary Anatomy and Histology, College of Veterinary Science and Animal Husbandry, OUAT, Bhubaneswar-751003, \\ Odisha, India
}

\begin{tabular}{|c|c|}
\hline Article Info & Abstract \\
\hline $\begin{array}{l}\text { Article history } \\
\text { Received } 4 \text { September } 2020 \\
\text { Revised } 27 \text { Ocotober } 2020 \\
\text { Accepted } 30 \text { October } 2020 \\
\text { Published online } 30 \text { December } 2020 \\
\text { Keywords } \\
\text { Immunomodulators } \\
\text { Antioxidants } \\
\text { Anti-inflammatory } \\
\text { Medicinal spices } \\
\text { Coronavirus }\end{array}$ & 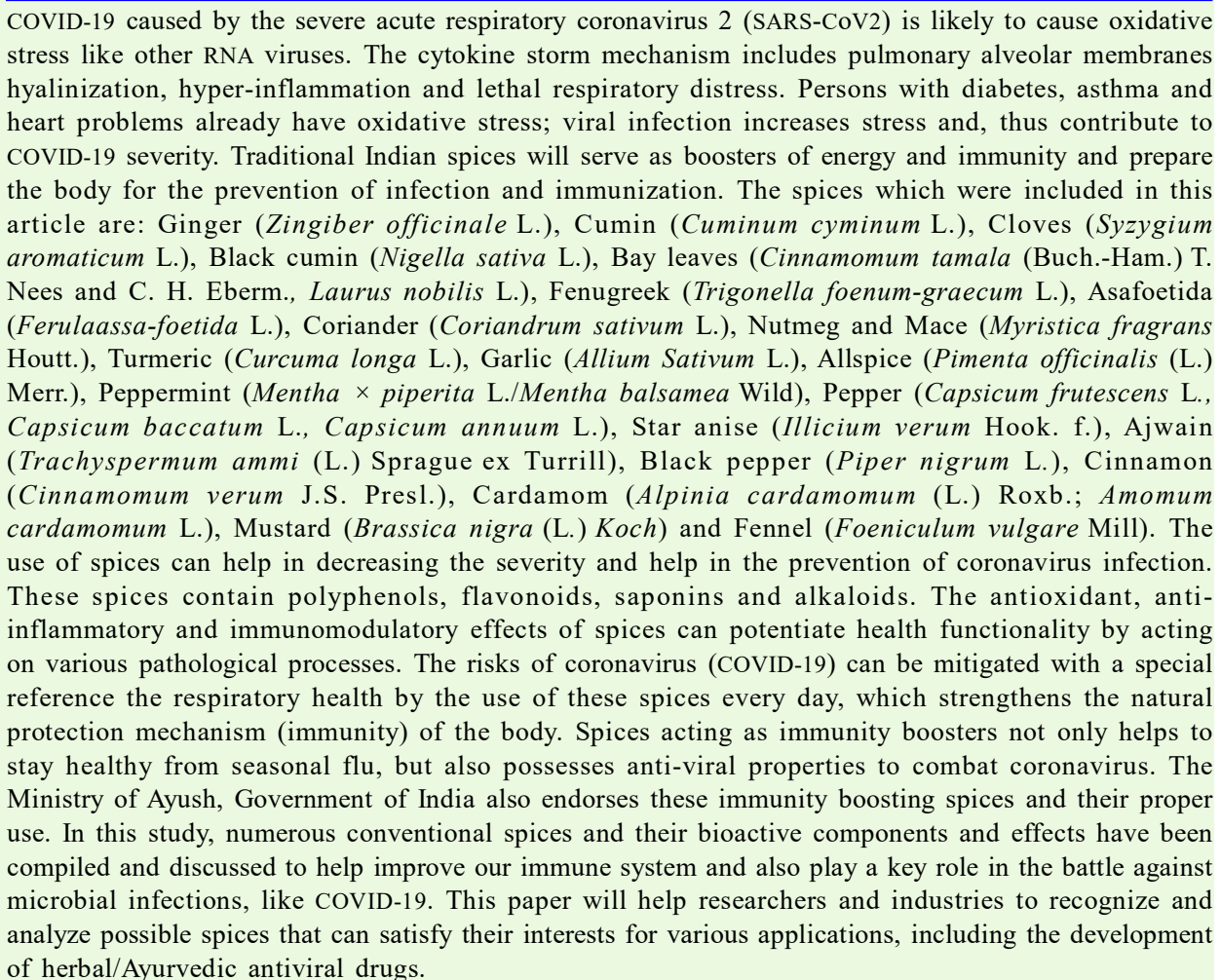 \\
\hline
\end{tabular}

\section{Introduction}

Coronavirus has crippled our day-to-day life and made the world experience depression. 'COVID-19', (Coronavirus disease 2019) is the new coronavirus belonging to the Coronaviridae family having 100 viruses, usually found in camels, cattle, cats and bats which accidentally spread to humans causing the dreadful disease. The respiratory illness called COVID-19, was first reported in

Corresponding author: Dr. Santwana Palai

Assistant Professor, Department of Veterinary Pharmacology and Toxicology, College of Veterinary Science and Animal Husbandry, OUAT, Bhubaneswar-751003, Odisha, India

E-mail: palaisantwana@gmail.com

Tel.: +91-9438298384

Copyright (c) 2020 Ukaaz Publications. All rights reserved.

Email: ukaaz@yahoo.com; Website: www.ukaazpublications.com
November 2019 in Wuhan, China which then spread rapidly to more than 80 countries globally as novel coronavirus. The virus when inside the body results in the 'cytokine storm' leading to the COVID-19 mortalities. SARS-Cov-2 selectively induces a high level of IL- 6 and results in the exhaustion of lymphocytes. The high level of cytokines is the cause of poor prognosis in COVID-19. Severely ill patients have a high concentration of pro-inflammatory cytokines, such as interleukin (IL)-6 in comparison to the moderately ill patients. Excessive pro-inflammatory cells, infiltration of T-helper cells and macrophages in lung of COVID-19 patients indicate the pathology of the cytokine storm in COVID-19 (Khan et al., 2020). Persons who are immuno-compromised, with pre-existing non-communicable diseases, cardiovascular disease, diabetes and poor nutritional status are more susceptible to 
COVID-19. Mortality results from cytokine storm and severe systemic inflammation. The time demands accelerated search for low cost, less side effect drugs with antioxidative, antiinflammatory and immunomodulatory effects which can check the cytokine storm.

Instead of searching for newer drug molecules, we need to explore our traditional herbal remedies for effective cure. Spices can be studied for their therapeutic action. It has been observed that countries with higher spice intake have fewer deaths and a higher rate of recovery from COVID-19. Although, no genetic predisposition to contract COVID-19 has been reported, there is variation in mortality rate. The potential correlation between COVID-19 and spice consumption has been analyzed including total cases, total mortality and total recovery. The overall figure of COVID-19 cases per million people tested and gram of spice supply per person per day was found to be clearly interrelated. Lower per capita spice intake nations have seen a higher number of COVID-19 cases per million people (Elsayed and Khan, 2020). This is not surprising because herbs and spices are believed to improve immunity. The trend of spice consumption may play a role in our ability to fight COVID-19. In this actual situation of lack of proven COVID-19 cure drugs/vaccines, herbal medicines for possible as antivirals and immune boosters. These spice extracts and formulations can aid in a good remedy for the reduction of the global COVID-19 mortality rate.

\section{Immunopathogenesis and stages of Covid-19}

The particulars regarding SARS-CoV2 virus is evolving rapidly and in the majority of the SARS-CoV2 infections, symptoms remain mild to moderate, while fatality occurs in some cases. The genetics and adaptive nature of this virus is not fully documented due to its high rate of mutation. However, symptoms from this virus progress slowly over an incubation period of about 14 days and the virus primarily replicates in the upper and lower respiratory tracts. In severe SARS-CoV2 infections, there is immunosuppression, leading to unchecked viremia, followed by a hyperinflammatory response exhibited clinically as an acute respiratory distress syndrome (ARDS) and multiorgan failure (Henri and Eric, 2020). Through, various mechanisms like using double membrane vesicles that lack pattern recognition receptors, hindering the Type 1 interferon production and downstream signaling, as well as enhancing the production of IL-10 (inhibitory cytokines), the virus tries to evade immune response. They also downregulate antigen presentation by MHC class I and II which diminishes T cell activation and shifts the Th1 response to a Th2 cytokine profile and promotes a $\mathrm{T}$ cell exhaustion (Rothan and Byrareddy, 2020).

\begin{tabular}{|c|}
\hline Coronaviruses have a positive-sense single-stranded RNA genome (27-34 kilobases). \\
\hline $\begin{array}{c}\text { Coronaviruses attach to complementary host cell receptors, and viral RNAs and viral structural protiens are replicated using } \\
\text { nonstructural protiens such as polyprotiens, RNA-dependent RNA-polymerase, and the host cell's ribosomes. }\end{array}$ \\
\hline $\begin{array}{c}\text { Human suffer most often from respiratory dysfunction, loss of taste and smell, the exacerbation of underlying diseases } \\
\text { such as cardiovascular disorders, and other organ involvements (Lechien et al., 2020). }\end{array}$ \\
$\begin{array}{c}\text { During the incubation period, the initiation of disease is due to substances that can induce injuries to lung cells and possibly other } \\
\text { organ cells are produced by SARS-CoV-2-infected cells. The potentially toxic or signalling substances spread systemically } \\
\text { and locally and then bind to receptors on the target organ cells that have an affinity for them (Shi et al., 2020). }\end{array}$ \\
$\begin{array}{c}\text { At the first stage, rapid and first-line immune responses are elicited } \\
\text { by innate and nonspecifiic T cell, possibly cytotoxic T-cell } \\
\text { activation, NK cell activation, antibody-dependent } \\
\text { cytotoxic reaction, and/or complement system } \\
\text { (Lee, 2015). }\end{array}$ \\
$\begin{array}{c}\text { In the second stage, the substances derived from injured target cells } \\
\text { or secondary infection induce further inflammation of the neighboring } \\
\text { lung tissue cells with corresponding immune cells and immune } \\
\text { protiens/broken lung barriers can induce further lung tissue } \\
\text { inflammation (Guo and Thomas, 2017). }\end{array}$ \\
$\begin{array}{c}\text { During immune responses to the virus, all host immune cells may communicate with each other, via, cytokine networks and major histocompatibility } \\
\text { complexes (Lee, 2015). Therefore, diverse immune proteins, including interleukin (IL)-1, IL-6, and tumor necrosis factor-alpha, and } \\
\text { other cytokines and immune proteins may be involved in inflammatory processes in COVID-19 and other immune-mediated diseases. } \\
\text { Blocking one of the inflammatory pathways could reduce inflammation and result in clinical improvement. }\end{array}$ \\
\hline
\end{tabular}

Figure 1: Immunopathogenesis and stages of Covid-19.

\section{Culinary spices as immunity booster}

The spices present in our kitchen are immunity promoters for health and well-being. Traditional medicines of India, China, Tibet, Japan include spices to boost immunity for ages. Spices are aromatic seasonings found as root, bud, bark, fruit, flower, seed, bulb and rhizome. Spices are commonly used to enhance flavour and colour of food. They can act as preservatives and remedies for diseases. The spices have antiviral and antibacterial actions too. Use of various spices in daily diet with pronounced antioxidant, antiinflammatory and immune boosting properties can be helpful in 
the prevention of influenza virus, coronavirus, etc. (Table 1). Spices are well-known to boost immunity like ginger (antibacterial and antiviral activities), garlic (antiviral, antibacterial and antifungal properties), Turmeric (antioxidant and anti-inflammatory effects), clove (antioxidants and antibacterial properties) and many more.

The Ayurveda Department of AYUSH, Ministry of Health and Family Welfare, Government of India has proved the antiviral activity of spices against viruses which can prevent coronavirus being immunity modulators. It has released National Clinical Management Protocol document, AyushKwath/AyushKudineer/ AyushJoshanda, which comprises of four medicinal herbs/spices like holy basil, cinnamon, ginger and black pepper (Wajpey, 2020). They are easily available and can be widely used as herbal home remedies and help in boosting the immune system of asymptomatic COVID-19 patients preventing the disease from turning severe. Preventive health interventions and recommendations for improved breathing health in covid-19 is possible through augmentation of immunity through use of traditional natural spices. Prolong stress, vitamin deficiencies, sleeplessness, exposure to toxin and old age imbalances the immune system. The innate immune cells are overstimulated, thus suppressing immune system components responsible for protection against viruses. Coronavirus causing COVID-19 spreads easily through the generation of infected person respiratory droplets in air or settled on surfaces. Persons coming in contact will show COVID-19 symptoms in mild, moderate or severe manner. Several clinical trials in laboratory animals with spices like cumin, turmeric and black pepper have depicted positive evidence for the anti-inflammatory, antiviral as well as immunomodulatory properties (Chauhan et al., 2010; Zahedipour et al., 2020; Rajagopal et al., 2020) of these natural compounds. The bioactive compounds of these spices help as an aid in the management of corona infections either by preventing the infection or by decreasing the severity of infection by balancing the immune functions. Also, they offer antioxidant and anti-inflammatory effects for curing cold and respiratory disorders of COVID-19. In absence of any curative measures for the deadly disease COVID-19, increasing your own immunity is best for coronavirus prevention. Intake of these immunity boosting spices in moderate amounts in form of KADHA on daily basis can be beneficial. They boost omega-3 production and lower cortisol levels in the body, thereby boosting the immune response.

Table 1: Effects of some culinary spices against Covid-19

\begin{tabular}{|c|c|c|c|c|c|c|}
\hline $\begin{array}{l}\text { Sr. } \\
\text { No. }\end{array}$ & $\begin{array}{l}\text { Name of the spice and } \\
\text { family }\end{array}$ & Bioactive compound & $\begin{array}{l}\text { Active } \\
\text { part }\end{array}$ & Uses & Other effects & References \\
\hline 1 & $\begin{array}{l}\text { Ginger } \\
\text { (Zingiber officinale L.) } \\
\text { Zingiberaceae }\end{array}$ & $\begin{array}{l}\text { Gingerols, shogaols, } \\
\text { paradols, zingerone }\end{array}$ & Root & Cold related ailments & $\begin{array}{l}\text { Anti-inflammatory, } \\
\text { anti-oxidative, } \\
\text { antimicrobial effects }\end{array}$ & $\begin{array}{l}\text { Park and } \\
\text { Pizzuto } \\
(2002) \\
\text { Ali } \text { et al. } \\
(2004)\end{array}$ \\
\hline 2 & $\begin{array}{l}\text { Cumin } \\
\text { (Cuminum cyminum L.) } \\
\text { Apiaceae }\end{array}$ & $\begin{array}{l}\text { t-anethole, p-cymene, } \\
\text { 4-terpineol, carvacrol, } \\
\text { longifolene, } \\
\text { nigelliciminepyrazol }\end{array}$ & Seeds & $\begin{array}{l}\text { Stimulant, carminative, } \\
\text { astringent, flatulence, } \\
\text { diarrhea }\end{array}$ & $\begin{array}{l}\text { Digestive, } \\
\text { anti-oxidativeeffects }\end{array}$ & $\begin{array}{l}\text { Ahmad } \\
\text { et al. (2013) }\end{array}$ \\
\hline 3 & $\begin{array}{l}\text { Cloves } \\
\text { (Syzygium aromaticum L.) } \\
\text { Myrtaceae }\end{array}$ & $\begin{array}{l}\text { Acetyl eugenol, beta- } \\
\text { caryophyllene, vanillin, } \\
\text { eugenin, kaempferol, } \\
\text { eugenitin, campesterol }\end{array}$ & $\begin{array}{l}\text { Flower } \\
\text { buds }\end{array}$ & $\begin{array}{l}\text { Anodyne/analgesic mainly } \\
\text { for dental emergencies } \\
\text { and other disorders }\end{array}$ & $\begin{array}{l}\text { Antioxidant, } \\
\text { antimicrobial activities }\end{array}$ & $\begin{array}{l}\text { Dibazar and } \\
\text { Daneshmandi } \\
(2015)\end{array}$ \\
\hline 4 & $\begin{array}{l}\text { Black cumin } \\
\text { (Nigella sativa L.) } \\
\text { Ranunculaceae }\end{array}$ & $\begin{array}{l}\text { Alkaloids, saponins, } \\
\text { sterols, and essential oil }\end{array}$ & Seeds & $\begin{array}{l}\text { Airway disorders, chronic } \\
\text { headache, paralysis, nback } \\
\text { pain, diabetes, }\end{array}$ & $\begin{array}{l}\text { Anti-inflammatory, } \\
\text { antihypertensive, } \\
\text { digestiveeffects }\end{array}$ & $\begin{array}{l}\text { Ahmad } \\
\text { et al. (2013) }\end{array}$ \\
\hline 5 & $\begin{array}{l}\text { Bay leaves (Cinnamomum } \\
\text { tamala (Buch.-Ham.) T. } \\
\text { Nees \& C.H.Eberm., } \\
\text { Laurus nobilis L.) } \\
\text { Lauraceae }\end{array}$ & $\begin{array}{l}\text { Eucalyptol } \alpha \text { - and } \beta \text { - } \\
\text { pinenes, phellandrene, } \\
\text { linalool, geraniol, } \\
\text { terpineol, lauric acid }\end{array}$ & $\begin{array}{l}\text { Leaves, } \\
\text { bark }\end{array}$ & $\begin{array}{l}\text { Alzheimer's disease, } \\
\text { diabetes, arthritis, } \\
\text { arteriosclerosis }\end{array}$ & $\begin{array}{l}\text { Antidiarrheal, } \\
\text { anti-inflammatory } \\
\text { antidiabetic activity }\end{array}$ & $\begin{array}{l}\text { Bilen and } \\
\text { Bulut (2010) }\end{array}$ \\
\hline 6 & $\begin{array}{l}\text { Fenugreek (Trigonella } \\
\text { foenum-graecum L.) } \\
\text { Fabaceae }\end{array}$ & $\begin{array}{l}\text { Trigonelline, cinnamic } \\
\text { acid, scopoletin }\end{array}$ & $\begin{array}{l}\text { Fresh } \\
\text { leaves, } \\
\text { seeds }\end{array}$ & $\begin{array}{l}\text { Constipation, } \\
\text { inappetance, } \\
\text { gastritis,diabetes, arthritis }\end{array}$ & $\begin{array}{l}\text { Antihypertensive breathing } \\
\text { problems, } \\
\text { antiulcerativeeffects }\end{array}$ & $\begin{array}{l}\text { Gong et al. } \\
(2016)\end{array}$ \\
\hline 7 & $\begin{array}{l}\text { Asafoetida } \\
\text { (Ferulaassa-foetida L.) } \\
\text { Umbelliferae }\end{array}$ & $\begin{array}{l}\text { Asaresinotannols A and } \\
\text { B, ferulic acid, } \\
\text { umbelliferone, 2-butyl- } \\
\text { propenyl-disulfide, } \\
\text { diallyl sulfide }\end{array}$ & Roots & $\begin{array}{l}\text { Indigestion, gases, } \\
\text { bronchitis, } \\
\text { kidney stones cancer, } \\
\text { type } 2 \text { diabetes }\end{array}$ & $\begin{array}{l}\text { Antioxidative, } \\
\text { anti-inflammatory, cardio } \\
\text { protective effects }\end{array}$ & $\begin{array}{l}\text { Zhang et al. } \\
(2015)\end{array}$ \\
\hline
\end{tabular}




\begin{tabular}{|c|c|c|c|c|c|c|}
\hline \begin{tabular}{|l|} 
Sr. \\
No.
\end{tabular} & $\begin{array}{l}\text { Name of the spice and } \\
\text { family }\end{array}$ & Bioactive compound & \begin{tabular}{|l} 
Active \\
part
\end{tabular} & Uses & Other effects & References \\
\hline 8 & $\begin{array}{l}\text { Coriander (Coriandrum } \\
\text { sativum L.) } \\
\text { Umbelliferae (Apiaceae) }\end{array}$ & $\begin{array}{l}\text { d-linalool/coriandrol } \\
\text { quercetin, } \\
\text { isoquercitrin, rutin }\end{array}$ & $\begin{array}{l}\text { Fruit, } \\
\text { leaves }\end{array}$ & $\begin{array}{l}\text { Gastrointestinal diseases, } \\
\text { respiratory ailments, pain, } \\
\text { loss of appetite and } \\
\text { memory, vitamin A, B, C } \\
\text { deficiencies, anxiety, } \\
\text { insomnia, smallpox }\end{array}$ & $\begin{array}{l}\text { Cholesterol-lowering, } \\
\text { anticholinesterase activity. } \\
\text { antioxidant, antibacterial, } \\
\text { antifungal, aphrodisiac, } \\
\text { antihyperglycemic, memory- } \\
\text { improving property }\end{array}$ & $\begin{array}{l}\text { Mandal and } \\
\text { Mandal } \\
(2015)\end{array}$ \\
\hline 9 & $\begin{array}{l}\text { Nutmeg and Mace } \\
\text { (Myristica fragrans } \\
\text { Houtt.) } \\
\text { Myristicaceae }\end{array}$ & $\begin{array}{l}\text { Myristicin, } \\
\text { elemicin, } \\
\text { safrole } \\
\text { dehydrodiisoeugenol }\end{array}$ & $\begin{array}{l}\text { Aril of } \\
\text { the fruit } \\
\text { (seed } \\
\text { case), } \\
\text { dried } \\
\text { kernel } \\
\text { (seed), }\end{array}$ & \begin{tabular}{|l|} 
Rheumatism stomachic, \\
carminative, \\
emmenagogue abortifacient, \\
inflammation, \\
pain thrombosis
\end{tabular} & $\begin{array}{l}\text { Anticancer, antioxidant, } \\
\text { antifungal antimicrobial, } \\
\text { anticarcinogenic, activities }\end{array}$ & $\begin{array}{l}\text { Checker } \\
\text { et al. }(2008)\end{array}$ \\
\hline 10 & $\begin{array}{l}\text { Turmeric } \\
\text { (Curcuma longa L.) } \\
\text { Zingiberaceae }\end{array}$ & $\begin{array}{l}\text { Curcuminoids, } \\
\text { curcumin }\end{array}$ & $\begin{array}{l}\text { Fresh } \\
\text { and dry } \\
\text { rhizomes }\end{array}$ & $\begin{array}{l}\text { Stomachache, } \\
\text { blood purifier, } \\
\text { carminative, cancer, } \\
\text { dermatitis, AIDS }\end{array}$ & $\begin{array}{l}\text { Anti-inflammatory, } \\
\text { antiemetic, } \\
\text { antifungal, antihepatotoxic, } \\
\text { antiarthritic activities }\end{array}$ & $\begin{array}{l}\text { Soni et al. } \\
(2020)\end{array}$ \\
\hline 11 & $\begin{array}{l}\text { Garlic (Allium Sativum L.) } \\
\text { Amaryllidaceae }\end{array}$ & $\begin{array}{l}\text { Allicin, } \\
\text { diallyl disulfide, } \\
\text { diallyl trisulfide, } \\
\text { allyl propyl disulfide }\end{array}$ & Bulbs & $\begin{array}{l}\text { Allergic-airway } \\
\text { infammation, } \\
\text { infammatory bowel } \\
\text { disease, rheumatism, } \\
\text { atherosclerosis, } \\
\text { cardiovascular diseases }\end{array}$ & \begin{tabular}{|l|} 
Antioxidative, antidiabetic, \\
antihypertensive, \\
antithrombotic, \\
antihypertensive, \\
immunommodulatory effects
\end{tabular} & $\begin{array}{l}\text { Clement } \\
\text { et al. }(2010) ; \\
\text { Moutia } \\
\text { et al. }(2018)\end{array}$ \\
\hline 12 & $\begin{array}{l}\text { Allspice } \\
\text { (Pimenta officinalis (L.) } \\
\text { Merr.) } \\
\text { Myrtaceae }\end{array}$ & $\begin{array}{l}\text { Eugenol, } \\
\text { gallic acid, } \\
\text { ericifolin }\end{array}$ & $\begin{array}{l}\text { Dried } \\
\text { unripe } \\
\text { berries }\end{array}$ & $\begin{array}{l}\text { Prostate cancer, } \\
\text { breast cancer Pesticides, } \\
\text { fungicides, food fumigant }\end{array}$ & $\begin{array}{l}\text { Antibacterial, hypotensive, } \\
\text { anti-neuralgic and analgesic } \\
\text { properties }\end{array}$ & $\begin{array}{l}\text { Zhang and } \\
\text { Lokeshwar } \\
(2012)\end{array}$ \\
\hline 13 & $\begin{array}{l}\text { Peppermint } \\
(\text { Mentha } \times \text { piperita } \text { L./ } \\
\text { Mentha balsamea } \text { Wild }) \\
\text { Lamiaceae }\end{array}$ & $\begin{array}{l}1,8 \text {-cineole, } \\
\text { menthone, } \\
\text { isomenthone, menthol, } \\
\text { pulegone, } \\
\text { caryophyllene }\end{array}$ & $\begin{array}{l}\text { Aerial } \\
\text { parts }\end{array}$ & $\begin{array}{l}\text { Colds, cramps, tonic, } \\
\text { colds, indigestion, nausea, } \\
\text { sore throat, toothache, } \\
\text { cancer carminative, } \\
\text { nausea, sore throat, } \\
\text { cancers, toothaches }\end{array}$ & $\begin{array}{l}\text { Antioxidant, cytotoxic, } \\
\text { antiallergenic, antibacterial, } \\
\text { antiviral, antifungal agent, } \\
\text { antispasmodic, antiseptic, } \\
\text { antifungal properties }\end{array}$ & 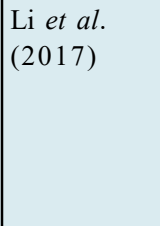 \\
\hline 14 & $\begin{array}{l}\text { Pepper } \\
\text { (Capsicum frutescens L., } \\
\text { Capsicum baccatum L., } \\
\text { Capsicum annuum L.) } \\
\text { Solanaceae }\end{array}$ & $\begin{array}{l}\text { Capsaicin, capsanthin, } \\
\text { capsorubin quercetin, } \\
\text { luteolin }\end{array}$ & Fruit & $\begin{array}{l}\text { Carminative, stomachic, } \\
\text { dropsy, colic, diarrhea, } \\
\text { asthma, arthritis, skin } \\
\text { rashes, dog/snake bite }\end{array}$ & $\begin{array}{l}\text { Hypoglycaemic, } \\
\text { hypocholesterolemic, } \\
\text { analgesic, anti-inflammatory, } \\
\text { antioxidant, antiviral, } \\
\text { anthelmintic and } \\
\text { antibacterial activities }\end{array}$ & $\begin{array}{l}\text { Zimmer } \\
\text { et al. }(2012)\end{array}$ \\
\hline 15 & \begin{tabular}{|l|} 
Star anise \\
(Illicium verum Hook. f.) \\
Magnoliaceae
\end{tabular} & $\begin{array}{l}\text { Anethole, shikimic } \\
\text { acid, } \alpha \text { and } \beta \text { pinene, } \\
\alpha \text {-phellandrene } \\
\text { myrcene, } \\
\text { limonene, linalool }\end{array}$ & Fruit & $\begin{array}{l}\text { Dyspepsia, flatulence, } \\
\text { spasmodic cough, } \\
\text { rheumarthritis, facial } \\
\text { paralysis }\end{array}$ & $\begin{array}{l}\text { Antimicrobial, } \\
\text { antiviral, antifungal, } \\
\text { anti-inflammatory, } \\
\text { antiallergic anticancer } \\
\text { antioxidant properties }\end{array}$ & $\begin{array}{l}\text { Patra et al. } \\
(2020)\end{array}$ \\
\hline 16 & $\begin{array}{l}\text { Ajwain } \\
\text { (Trachyspermumammi } \\
\text { (L.) Sprague ex Turrill) } \\
\text { Apiaceae }\end{array}$ & $\begin{array}{l}\text { Thymol, carvacrol, } \\
\text { tannins, glycosides, } \\
\text { saponins, flavone }\end{array}$ & $\begin{array}{l}\text { Seed, } \\
\text { leaf }\end{array}$ & $\begin{array}{l}\text { Acidity, flatulence, } \\
\text { asthma, arthritis, migraine } \\
\text { headache and common } \\
\text { cold }\end{array}$ & $\begin{array}{l}\text { Antibacterial, insecticidal, } \\
\text { nematicidal, hypotensive, } \\
\text { anti-tussive effects }\end{array}$ & $\begin{array}{l}\text { Chahal } \\
\text { et al. (2017); } \\
\text { Rajeshwari } \\
\text { et al. }(2011)\end{array}$ \\
\hline 17 & $\begin{array}{l}\text { Black pepper (Piper } \\
\text { nigrum L.) } \\
\text { Piperaceae }\end{array}$ & $\begin{array}{l}\text { Piperine, pinene, } \\
\text { terpenene, limonene, } \\
\text { mercene, } \alpha \text {-terpineol, } \\
\alpha \text {-pinene, piperolnol }\end{array}$ & Fruit & $\begin{array}{l}\text { Appetitzer, cures cold, } \\
\text { cough, colic, dysentery, } \\
\text { worms }\end{array}$ & $\begin{array}{l}\text { Antimicrobial, analgesic, } \\
\text { antipyretic } \\
\text { anti-inflammatory, } \\
\text { hepatoprotective, } \\
\text { antioxidant }\end{array}$ & $\begin{array}{l}\text { Srinivasan } \\
(2007)\end{array}$ \\
\hline
\end{tabular}




\begin{tabular}{|c|c|c|c|c|c|c|}
\hline $\begin{array}{l}\text { Sr. } \\
\text { No. }\end{array}$ & $\begin{array}{l}\text { Name of the spice and } \\
\text { family }\end{array}$ & Bioactive compound & $\begin{array}{l}\text { Active } \\
\text { part }\end{array}$ & Uses & Other effects & References \\
\hline 18 & $\begin{array}{l}\text { Cinnamon (Cinnamomum } \\
\text { verum J.S. Presl.) } \\
\text { Lauraceae }\end{array}$ & $\begin{array}{l}\text { Cinnamaldehyde, } \\
\text { cinnamate, } \\
\text { cinnamic acid, and } \\
\alpha \text {-thujene }\end{array}$ & Bark & $\begin{array}{l}\text { Astringent, stimulant and } \\
\text { carminative } \\
\text { Treating nausea, } \\
\text { vomition, heart burn }\end{array}$ & $\begin{array}{l}\text { Anticancer, antidiabetic, } \\
\text { antimicrobial, } \\
\text { anti-inflammatory, } \\
\text { antioxidant, cholesterol } \\
\text { and lipid lowering effects }\end{array}$ & $\begin{array}{l}\text { Yu and Yang } \\
(2012)\end{array}$ \\
\hline 19 & $\begin{array}{l}\text { Cardamom } \\
\text { (Alpinia cardamomum } \\
\text { (L.) Roxb.; Amomum } \\
\text { cardamomum L.) } \\
\text { Zingiberaceae }\end{array}$ & $\begin{array}{l}1,8 \text {-cineole, terpene, } \\
\text { esters, flavonoids, } \\
\text { Cineole }\end{array}$ & Fruit & $\begin{array}{l}\text { Respiratory disorders, } \\
\text { stomach complaints, bad } \\
\text { breath, sore throat, colds, } \\
\text { fever, bronchitis, } \\
\text { flatulence, and colic }\end{array}$ & $\begin{array}{l}\text { Antiseptic, expectorant } \\
\text { activity, anti-inflammatory, } \\
\text { antioxidant, } \\
\text { immunostimulant effects }\end{array}$ & $\begin{array}{l}\text { Sapra et al. } \\
(2020)\end{array}$ \\
\hline 20 & $\begin{array}{l}\text { Mustard (Brassica } \\
\text { nigra }(\text { L.) Koch) } \\
\text { Brassicaceae }\end{array}$ & $\begin{array}{l}\text { Allyl isothiocyansinalexin, } \\
\text { sinalbins A and B, } \\
\text { sitosterol, campesterol, } \\
\text { apigenin, chalcone, } \\
\text { sinapic acid, and sinapine }\end{array}$ & Seed & $\begin{array}{l}\text { Peritonitis, } \\
\text { neuralgiarheumatism, } \\
\text { arthritis, chest } \\
\text { congestion, back pain, } \\
\text { muscular ache }\end{array}$ & $\begin{array}{l}\text { Antidiabetic, anticonvulsant, } \\
\text { antithrombotic, antibacterial, } \\
\text { antifungal, antioxidant, } \\
\text { immunomodulatory, anti- } \\
\text { inflammatory effects }\end{array}$ & $\begin{array}{l}\text { Tian and } \\
\text { Deng }(2020)\end{array}$ \\
\hline 21 & $\begin{array}{l}\text { Fennel (Foeniculum } \\
\text { vulgare Mill) } \\
\text { Apiaceae }\end{array}$ & $\begin{array}{l}\text { Anethole, alpha pinene, } \\
\text { beta myrcene, beta } \\
\text { pinene, bitter } \\
\text { fenchone, camphene, } \\
\text { estragole (methyl- } \\
\text { chavicol), fenchone, } \\
\text { limonene, p-cymen, } \\
\text { and safrole }\end{array}$ & $\begin{array}{l}\text { Fruit, } \\
\text { leaf, } \\
\text { seed }\end{array}$ & $\begin{array}{l}\text { Abdominal pains, } \\
\text { vomition, arthritis, } \\
\text { cancer, constipation, } \\
\text { laxative, leucorrhoea, } \\
\text { liver pain, mouth ulcer, } \\
\text { stomachache }\end{array}$ & $\begin{array}{l}\text { Antifungal, antibacterial, } \\
\text { antiviral, antiprotozoal, } \\
\text { antitumor, antioxidant } \\
\text { effects, chemopreventive, } \\
\text { cytoprotective, } \\
\text { hepatoprotective, activities }\end{array}$ & $\begin{array}{l}\text { Zhu et al. } \\
(1999)\end{array}$ \\
\hline
\end{tabular}

\section{Effects of some culinary spices against Covid-19}

The first line of defence against COVID-19 appears to be immune system and researches around the world are focusing on how to strengthen it. Spices have many natural ingredients that boost the immunity, acting as immunomodulatory, antioxidative and antiinflammatory agents as demonstrated in many studies.

\subsection{Ginger (Zingiber officinale $\mathrm{L}$.)}

It is an herbaceous perennial which grows false stems made of the rolled bases of leaves (pseudostems). The rhizome, which is the horizontal stem from which the roots grow, is the portion of ginger that is consumed. Its spicy aroma is mainly due to presence of ketones, and gingerols.

\section{- Immunomodulatory effect}

Gingerol, the active component of ginger reduces NO (nitrous oxide) production by host mononuclear cells and might have a direct effect on NO production. It reduces iNOS (inducible nitric oxide synthase) and TNF- $\alpha$ expression by blocking NF- $\mathrm{KB}$ (Nuclear factor kappalight-chain-enhancer of activated $\mathrm{B}$ cells) and protein kinase C signalling (Amri and Touilboukoffa, 2016).

\section{- Effect on respiratory system}

The bioactive components of ginger like gingerols and shogaols have the ability to mediate anti-inflammatory effects (Kim et al., 2005). Sore throat which is a common symptom of coronavirus, can be relieved by the anti-inflammatory effect of ginger.

\section{- Effect on coronavirus}

The antiviral properties of ginger are due to the presence of antioxidant compounds and potential anti-inflammatory as well as immuneboosting characteristics. Being a pungent and spicy herb, ginger heats up the body which is desired during exposure to the virus.

The hot water extract of fresh ginger is effective against HRSV (Human Respiratory Syncytial Virus), induced plaque formation on airway epithelium by blocking viral attachment. The results of a study also indicated that aqueous extract of ginger is very effective in prevention of the contamination of fresh vegetables (Mao et al., 2019).

\subsection{Cumin (Cuminum cyminum $\mathrm{L}$.)}

Cumin is the dried seed of the herb Cuminum cyminum that grows to about $30-50 \mathrm{~cm}$ height and is an annual herbaceous plant, with a slender, branched stem that is $20-30 \mathrm{~cm}$ tall. The important part of cumin used in traditional medicine (cumin oil) is extracted from the ripe and dried ripe fruit. The major benefits rendered by cumin are related to the immune and digestive systems of the human body.

\section{- Immunomodulatory effect}

Experimental studies on the administration of cumin exemplified immunomodulatory activity through modulation of T lymphocytes. A significant increase of T cells (CD4 and CD8) count and Th1 predominant immune response in a dose dependent manner was observed. There was depletion of $\mathrm{T}$ lymphocytes and elevation in corticosterone levels and size of adrenal glands in case of restraint immune-suppressed animals. There was also an increase in the weight 
of thymus and spleen indicating that $C$. cyminum is an effective immunomodulator recovers immunity of immuno-compromised persons (Chauhan et al., 2010)

\section{- Effect on respiratory system}

Cumin oil has been used extensivelyin broncho pulmonary disorders and in cough treatment as well as an analgesic (Lang and Buchbauer, 2011).

\section{- Effect on coronavirus}

The cumin oils exhibit high antioxidant activity which can be accredited to various phytoconstituents like alcohols, linalool, carvacrol, anethole and estragol, flavonoids, monoterpene and polyphenolic compounds. The antiradical profile of cumin has been proposed as the chief mechanism for their many pharmacological properties including antiviral activities (Martino et al., 2009).

\subsection{Cloves (Syzygium aromaticum $\mathrm{L}$.)}

It is a tropical evergreen tree of the family myrtaceae and its small reddish-brown flower buds are used as a spice. Flower buds are collected in the maturation phase before flowering. They have been known for its medicinal values, have a spicy and pungent taste and rich in vitamins, minerals, and fibre.

\section{- Immunomodulatory effect}

In experimental studies with clove extracts, nitric oxide (NO) production was suppressed due to antioxidant activity of clove and some of its individual constituents. Mainly dose-related and bi-phasic effects of the clove are seen on macrophage cytokine formation or release of IL- 6 and TNF $\alpha$, and unremarkable effects on IL-12 suggest a lesser immunomodulatory effect (Dibazar and Dineshmandi, 2015).

\section{- Effect on respiratory system}

Clove oil has a benefit of treating the respiratory illness like asthma. It also helps in opening the breathing passages and provides relief for few of the symptoms of coronavirus. It also helps in reducing inflammation and prevents bacteria from forming colonies in the lungs.

\section{- Effect on coronavirus}

The bioactive components of clove essential oil displayed many antioxidant and antiviral activities. They showed an inhibitory effect against certain RNA of the respiratory syncytial virus (RSV), and DNA of some enveloped virus. The two phytochemicals, betulinic acid and savinin, which are found in the essential oil of cloves inhibit post binding entry of severe acute respiratory syndrome (SARS) coronavirus into cells. Cloves act directly upon the virus envelope like coronaviruses (COVID-19), besides anti-platelet activities prevent the formation of a thrombus or a blood clot. Therefore, essential oil of cloves may be considered to combat corona virus and protection against sudden death seen in some patients infected by coronavirus resulting from embolism associated with hyper coagulable formation (Jayyab, 2020).

\subsection{Black cumin (Nigella sativa L.)}

Black cumin plants are hardy annuals that grow 20 to $60 \mathrm{~cm}$ in height. The stem is branched with fine, extremely divided leaves. The five-petal bearing pale blue or white flowers with numerous stamens and fused carpals. The oil and seed component, thymoquinine (TQ) shows likely medicinal actions.

\section{- Immunomodulatory effect}

The extracts and thymoquinine can be effective therapeutic agent for regulation of immune responses in many non-infectious and infectious diseases. This can be attributed to the increase in figure and purpose of CD4 $\mathrm{T}$ cells and increased production of INF-gamma (Majdalawieh and Fayyad, 2015).

\section{- Effect on respiratory system}

A lower degree of pulmonary inflammation and tracheal sensitivity was revealed by studies on effect of black cumin. Black cumin extract shows significant raise in respiratory function tests. The bronchodilator effect of $N$. Sativa extract was as good as theophylline (Boskabady et al., 2011)

\section{- Effect on coronavirus}

The in silico studies recommend $N$. sativa as a potent phytotherapeutic agent against COVID-19. Some compounds of $N$. sativa, like nigelledine, $\alpha$-hederin, hederagenin, thymohydroquinone revealed high to moderate affinity with SARS-CoV-2 enzymes and proteins as they inhibit SARS-CoV-2 duplication and addition to host cell receptors (Koshak and Koshak, 2020). The oil obtained from $N$. sativa seeds have been reported to be active against avian influenza virus subtype H9N2 (Smith and Brennessel, 1994). Also, N. sativa slows down COVID-19 pathogenesis than the standard drugs. On the basis of molecular studies, $N$. sativa components like thymoquinone, nigellidine, and $\alpha$-hederin have a good potential in reinforcing the immune response (Kulyar et al., 2020).

\subsection{Bay leaves (Cinnamomum tamala (Buch.-Ham.) T. Nees and C. H. Eberm., Laurus nobilis $\mathbf{L}$.)}

It is an aromatic evergreen tree or large shrub with green, glabrous smooth leaves. The plant has a good depository of phytoconstituents most of which are found in bark. The essential oils show important biological activities such as antidiarrheic, anti-arthritic, antitumor actions.

\section{- Immunomodulatory effect}

The extracts from $C$. tamala contain trans-cinnamaldehyde and its analogues showing remarkable protective actions (Upadhyay et al., 2016).

\section{- Effect on respiratory system}

Bay tea is used to clear up mucus in the lungs, cure colds, and sore throat.

\section{- Effect on coronavirus}

L. nobilis essential oil showed analgesic and anti-inflammatory activities in laboratory animals. The extract obtained from the seeds and leaves of bay leaf showed anti-inflammatory properties (Kozan et al., 2006). L. nobilis essential oil containing 1,8-cineol, alphapinene, beta-ocimene, beta-pinene showed SARS-CoV inhibitory activity (Bilen and Bulut, 2010). Ethanol extracts of $L$. nobilis reported powerful antioxidant activities by evaluating free radical and hydrogen peroxide superoxide anion radical scavenging and 
metal chelating assays. The antioxidant activity is attributed to the presence of phenolic compounds like gallic acids and butylated hydroxyl anisole (Elmastas et al., 2006).

\subsection{Fenugreek (Trigonella foenum-graecum L.)}

It is an erect, smooth, herbaceous plant that can grow up to a height of $40-80 \mathrm{~cm}$ and is tap-rooted. The stems are branched. The fenugreek seeds benefits include action as hepatoprotective, hypocholesterolemic, antidiabetic, lactation aid, anticancer agent (Al Snafi, 2016).

\section{- Immunomodulatory effect}

The fenugreek can augment immunity and is also influential in healing the symptoms of flu (Srinivasan, 2006)

\section{- Effect on respiratory system}

Fenugreek has proven useful in relief against bronchial disorders, colds, sore throat, sinusitis, influenza, catarrh, asthma, pleurisy, laryngitis, pneumonia and emphysema.

\section{- Effect on coronavirus}

Fenugreek also acts as a mucus solvent and a throat cleanser, thereby easing the urge to cough. As these are symptoms experienced in COVID-19 infection, fenugreek is beneficial for curing disorders like cough and cold like viral respiratory infection.

\section{- Antioxidant effect}

It also has antioxidant property. The cellular debris masses can be softened and dissolved by drinking fenugreek seeds-soaked water (Naidu et al., 2011).

\subsection{Asafoetida (Ferulaassa-foetida L.)}

Ferula plants with massive taproots of about $15 \mathrm{~cm}$ in diameter at 4-5 years old yields asafoetida with antinociceptive and antiinflammatory effects. The milky juice exudates from the cut surface are collected after scraping them with or without the resin. The recurrent process of resin collection and root slicing is done till caseation of exudate occurs (Amalraj and Gopi, 2016).

\section{- Anti-inflammatory effect}

The anti-inflammatory activity of asafoetida is seen using the carrageenan in mouse paw edema where asafoetida showed an anti-inflammation effect. Asafoetida makes potent anti-inflammatory activity by inhibiting inflammatory processes. Umbelliprenin, which is one of the sesquiterpene coumarins of asafoetida, can inhibit the activity of 5-lipoxygenase and shows the anti-inflammatory action. Umbelliprenin of asafoetida, also inhibits the activity of 5-lipoxygenase and shows the anti-inflammatory action having potent nuclear factor- $\kappa \mathrm{B}$-inhibiting properties. Ferulic acid is another component of asafoetida with powerful antioxidant property, acts as an anti-inflammatory agent extending analgesic effect (Bagheri et al., 2016).

\section{- Antioxidant effect}

The enzymatic hydrolysis of the spice through the action of pepsin and purification exhibited better antioxidant activity in many radical scavenging assays like superoxide radical assays, FRAP, and ABTS. (Amalraj and Gopi, 2016).

\subsection{Coriander (Coriandrum sativum L.)}

It is a culinary as well as a medicinal plant that is a source of aromatic compounds and essential oils useful in food preparation (as a flavouring agent and adjuvant) and in the prevention of food borne diseases and food spoilage. It has a culinary value that aids to its nutritional value. The spice is herbaceous, annual, with white flowers and a height of 30-60 cm. It is a glamorous, herbaceous annual vine. This plant is primarily cultivated for its fruit and/or leaves, which are used for various purposes, such as food, medicines, cosmetics and perfumes (Mandal and Mandal, 2015).

\section{- Immunomodulatory effect}

Spices also contain many bioactive phytochemicals, including flavonoids (quercetin, rutin) and coumarins (bergapten, isopimpinelline, xanthotoxine) that are effective against allergy, inflammation, and immunosuppression. Dietary phytonutrients, including vitamins, possess immunomodulatory and antiviral activity. The bioactive components like p-coumaric acid, ferulic acid, caffeic acid and chlorogenic acid found in coriander have been observed to increase the activity of human lymphocyte proliferation and IFN-c secretion. Flavonoid, quercetin and coumarin isopimpinellin contribute to the immune enhancement by lymphocyte activation, while flavonoids (quercetin and rutin) and coumarins (bergapten, xanthotoxin) contribute to the immune stimulation by IFN-c secretion (Mandal and Mandal, 2015).

\section{- Anti-inflammatory effect}

Linalool substantially decreases carrageenin-induced oedema in rats and demonstrated the major role of linalool in the anti-inflammatory action of the essential coriander seed oil. Furthermore, free radical scavenging property of coriander oil is attributable to terpenes and oils such as polyunsaturated fatty acids, unsaponifiables, and phospholipids (Reuter et al., 2008).

\section{- Antioxidant effect}

Coriander is abundant in antioxidants to disrupt or avoid spoiling food which proves it to be a preservative. Coriander fruit displayed greater antioxidant activity than its essential oils due to its 2,2diphenyl-1-picryl hydrazile (DPPH) RSA scavenging capability. Antioxidant effects on vascular pathology and endothelial integrity are associated with cardiovascular and lung disease (Singletary, 2016).

\subsection{Nutmeg and Mace (Myristica fragrans Houtt.)}

The nutmeg tree (Myristica fragrans) is a tropical, evergreen, aromatic tree, usually 5 to 13 meters tall. The pointed dark green leaves are alternately arranged along the branches and are around $1 \mathrm{~cm}$ long on the leaf stems. The surfaces of the upper leaf are shiny. The fruit is fleshy, drooping, yellow, flat, 6 to $9 \mathrm{~cm}$ long with a longitudinal ridge. When mature, the succulent yellow fruit coat is divided into two valves that expose a purplish-brown, shiny seed (nutmeg) surrounded by a red aril (mace). Seeds are roughly 2 to $3 \mathrm{~cm}$ long, oval, white and transverse, fleshy with red-brown veins. The aril (mace) is bright scarlet colour when fresh and a yellowish-brown in colour when dried (Jaiswal et al., 2009). 


\section{- Immunomodulatory effect}

The lignans present in the fresh nutmeg mace showed immunomodulatory effects. Quercetin from $M$. fragrans can inhibit various cytokines including IL-1 $\beta$, IL-6 and TNF- $\alpha$ (Dewi et al., 2015). The immunomodulatory activities of lignans present in fresh nutmeg mace aqueous extract inhibited the transcription of IL-2 and IL-4 genes while responding topolyclonal T-cell mitogen concanavalin A(Con A). The production of IL-4, IL-2 and IFN-gamma cytokines were withdrawn by mace lignans in Con A-stimulated lymphocytes in a dose-dependent manner (Checker et al., 2008).

\section{- Anti-inflammatory effect}

Nutmeg contains essential oils, many of which have been reported to possess analgesic and anti-inflammatory properties. The chloroform extract of the seeds of $M$. fragrans demonstrated anti-inflammatory activity by inhibiting the carrageenan-induced rat paw oedema. This finding tends to support the local use of essential oil in rheumatism. The oil of $M$. fragrans has been shown to decrease prostaglandin levels in rats. Prostaglandins are considered to be one of the main mediators of inflammatory processes. This shows that the extract of nutmeg had a very strong analgesic effect (Olajide et al., 1999).

\section{- Antioxidant effect}

It has been observed that nutmeg and its active compounds have antioxidant properties. Antioxidant activity was calculated using a 1,1-diphenyl-2-picrylhydrazyl radical-scavenging process, a superoxide dismutase assay, a ferric thiocyanate assay, and a radical-scavenging electron-spin resonance assay. Nutmeg extract had a high overall phenolic content, was strongly inhibited by the formation of TBARS and had a strong DPPH scavenging operation. Daily use of nutmeg along with other spices can prevent a postprandial increase in glucose levels by inhibiting intestinal alpha-glucosidase for maintaining blood glucose levels through secretagogue action of insulin (Charles, 2012).

\subsection{Turmeric (Curcuma longa $\mathrm{L}$.)}

Curcuma longa, generally referred to as turmeric, is a tropical perennial belonging to the Zingiberaceae family. Typically, it grows to nearly $7-10 \mathrm{~cm}$ height in a foliage cluster of ornamentallyattractive, cannate-like, elliptical to lanceolate green leaves (each about $4 \mathrm{~cm}$ ). In summer, small dense spikes of pale-yellow flowers are produced. This plant has rhizomes, which when ground yields bright yellow colour spice with pungent and bitter flavour.

\section{- Immunomodulatory effect}

Huge pro-inflammatory cytokines in haematopoiesis weakens immunity and decreases immune cell differentiation in COVID-19 patients. Curcumin, an active component of turmeric can enhance the hematopoietic differentiation of the immune cells and is evident as an immunomodulator. Curcumin modulates the immune response by suppressing the spread of lymphocytes and the development of cytokines by targeting the activation of the NF- $\mathrm{\kappa B}$ transcription factor (Srivastava et al., 2011).

\section{- Effect on coronavirus}

Curcumin can modulate the cellular entry and replication of SARSCoV-2, which manifests its effect on the immunopathological actions of COVID-19. The protection and prevention of cell, tissue and organ damage and cell differentiation results in benefits in COVID-19 patients. In addition, the ability to enhance the efficacy of other drugs in antiviral settings supports the use of curcumin as an adjuvant with several benefits. Collectively, curcumin can modulate pathophysiological consequences of SARS-CoV-2. Pulmonary fibrosis occurs in sequalae with SARS-CoV-2 infection where mTOR (mammalian target of rapamycin) is the target. Curcumin has been tested as an inhibitor of mTOR and, thus the recurrence of this golden spice ingredient will offer health benefits to COVID-19 patients. MTOR has also been seen in age-related illnesses. Curcumin-mediated inhibition of mTOR can result in better prognosis in elderly patients infected with SARS-CoV-2 (Huang et al., 2020).

\section{- Anti-inflammatory effect}

Cytokines involved in the cytokine storm include IL-1, IL-2, IL-6, IL-10, transforming growth factor (TGF)- $\beta$, interferons (IFN) and TNF- $\alpha$. Expressions of IL- 6 and TNF- $\alpha$ are mainly related to COVID-19 associated acute respiratory disease syndrome and organ damage. Curcumin has been shown to attenuate influenza-induced lung inflammation by inhibiting NF- $\mathrm{KB}$ signalling. In addition, an increase in pulmonary inflammation and associated damage was found to be associated with the induction of NF- $\mathrm{KB}$ in airway epithelium. The inhibitory effect of curcumin on IFN- $\alpha$ and other inflammatory cytokines is related with inhibition of NF- $\kappa$ B. The suppressive action of curcumin in the development of inflammatory cytokines ameliorates pulmonary fibrosis (Zahedipour et al., 2020).

\section{- Antioxidant effect}

The high antioxidant activity of turmeric is triggered by curcuminoids which are phenolic compounds. Turmeric oils and oleoresin are also important antioxidants. Alpha-turmerone is the main constituent of necessary oil and oleoresin. The compounds like sitosterol, curcumene, santalene exert either synergistic or additive action exhibiting total antioxidant activity of $C$. longa rhizomes (Singh et al., 2010).

\subsection{Garlic (Allium Sativum L.)}

Garlic plants are nearly 2 feet in height. Long leaves usually originate from a small hard stem above the bulb with overlapping leaf sheaths. The bulb is coated with membranous skin and contains up to 20 edible bulbs called cloves. Flower stalks often appear bearing tiny secondary bulbs that form in place of flowers.

\section{- Immunomodulatory effect}

Fructo-oligosaccharides (FOS) are normal fructans found in garlic are immunomodulatory in nature. Abundantly, present garlic agglutinins ASA I and ASA II (Allium sativum agglutinin I and II) are found to be potent mitogens with possible efficacy in therapeutic immunomodulation (Clementer, 2010). Garlic stimulates macrophage phagocytosis and spread of lymphocytes inducing the infiltration of macrophages and lymphocytes in transplanted tumours, stimulates the release of IL-2, TNF-alfa and IFN-gamma, enhance natural killer (NK) cells, lymphocyte-activated killer cell activity, thus inducing the immune response. Garlic can also be useful in preventing the suppression of the immune response (Venkatesh, 2018). 


\section{- Anti-inflammatory effect}

Garlic compounds activate the T-lymphocyte and CD8+ cells and also slow the sensitivity of the cells and tissues of the body. Effect on IL-10 and IL-12 directly and IFN gamma production in T and NK cells indirectly prove the anti-inflammatory effects of garlic extracts in inflammatory diseases. Allicin, an essential garlic compound, inhibited the secretion of TNF-alfa by encouraging the anti-inflammatory effect of allicin on intestinal epithelial cells (Moutia et al., 2018).

\section{- Antioxidant effect}

A. sativum is loaded with antioxidants that help to kill free radical particles that can cause cell membranes damage and lead to the ageing process and development of conditions such as heart disease and cancer. Garlic extract having stable organosulphur compounds evade scavenging free radicals oxidative damage. Garlic derivatives affect various molecular processes, such as free radical scavenging, DNA adduct formation, angiogenesis, etc. (Capasso, 2013).

\subsection{Allspice (Pimenta officinalis (L.) Merr.)}

The tall slender tree has a white-gray trunk and aromatic deep green leaves. Tiny white flowers emerge in the spring, and when the plant is ripe, dark purple berries bear fruit in the summer. Many of these compounds such as eugenol, quercetin, gallic acid and others are isolated from other sources too. The most important ingredient isolated from Allspice with high antioxidant activity is eugenol, which comprises 60-90 per cent of the essential oil extracted from Allspice berries. Eugenol prevents the growth of several pathogens and has a synergistic effect with known antibiotics (Embuscado, 2015).

\section{- Anti-inflammatory effect}

The anti-inflammatory activity of activated macrophages caused by LPS, of which eugenol has an inhibitory effect on its development of COX-2, as well as the activation of the NF-KB pathway, characteristics of inflammation, has been investigated. Quercetin is a supplement found in Allspice berries with potent anti-inflammatory and anti-oxidant effect. Ericifolin (Eugenol 5-O-galloylglucoside), the oil of Allspice also displayed anti-inflammatory activity (Zhang and Lokeshwar, 2012).

\section{- Antioxidant effect}

Allspice is known for its antioxidant activity and possesses polyphenols with high antioxidant activity and free radical-scavenging activity against DPPH radicals. Eugenol is also well known for its antiinflammatory and antioxidant role. Radical-scavenging against DPPH assays has been used to test the antioxidant activity of eugenol and has shown promising results. Quercetin is a component of Allspice and has a strong antioxidant effect. Its potent ROS scavenging feature, which reduces DNA damage, can significantly contribute to the potential antioxidant effect of Allspice extracts, as well as to the potential benefit associated with their consumption (Embuscado, 2015).

\section{- Antiviral effect}

Quercetin has been reported to have antiviral activity against various types of virus, and has also been shown to protect cardiovirus-infected mice. The mechanisms for the anti-inflammatory effect of Quercetin are the down-regulation of the NF-KB pathway, inhibition of the expression of inflammatory cytokines and inhibition of the expression of inflammatory genes. Its component, gallic acid has been also shown to have antiviral effects (Zhang and Lokeshwar, 2012).

4.13 Peppermint (Mentha $\times$ piperita L./Mentha balsamea Wild)

It is a hybrid mint, is a cross species between watermint and spearmint, famous for its flavouring and medicinal properties and is used in food, cosmetics, and medicines. It is an aromatic rhizomatous perennial herb reaching up to $30-90 \mathrm{~cm}$ and its stems erect, quadrangular. The generally branched stems are frequently tinged violet or purplish. The dim or light green leaves are oblongovate, opposite, serrate and short-petiole with their toothed margins and its range between 4 and $5 \mathrm{~cm}$ long. Flowers are purple or reddish, $8 \mathrm{~mm}$ long, false spikes with many bracts inconspicuous. Fruit consists of four ellipsoidal nutlets.

\section{- Immunomodulatory effect}

M. piperita could enhance innate immunity, which is beneficial to counteract RSV infection in addition to directly interfering with viral entry without exacerbating the illness during the management of RSV infection. The immunomodulatory action of $M$. piperita is seen by intraperitoneal administration of peppermint oil, 1- menthol and 1,8-cineole to anaphylactic guinea-pigs. Dietary peppermint extracts support growth performance, have immunostimulant properties increasing hematological parameters (Adel et al., 2015).

\section{- Anti-inflammatory effect}

The essential oil and extract of $M$. piperita were evaluated for their anti-inflammatory activities. The carrageenan-induced hind paw oedema model, croton oil induced ear oedema and in vitro nitric oxide (NO) production was utilized as a widely used screening protocol. In many inflammatory disorders, there is excessive phagocyte activation and production of hydroxyl, superoxide anion, and non-free-radical species $\left(\mathrm{H}_{2} \mathrm{O}_{2}\right)$ that are harmful to tissues which provokes an inflammatory response by producing mediators and chemostatic factors. It restrains the making of TNF-alfa, IL-6, NO, and $\mathrm{PGE}_{2}$. The anti-inflammatory activity could be beneficial in fighting respiratory infections. Menthol suppressed the production of the inflammatory mediating compounds like leukotriene, prostaglandin and interleukin (McKay and Blumberg, 2006).

\section{- Antioxidant activity}

Pharmacological studies demonstrated that the volatile oil and extracts of $M$. piperita have strong antioxidative effects. The peppermint essential oils or extracts scavenge reactive oxygen species by DPPH (1,1-diphenyl1-picrylhydrazil or 2,2-diphenyl1-picrylhydrazil) ILPA, (inhibition of lipid peroxidation assay), ISRA (inhibition of superoxide radicals assay). The antioxidant activity of peppermint can reduce cellular damage that causes lipid peroxidation and inflammation and may have a positive effect in preventing the progression of many human diseases caused by free radicals. The $M$. piperita leaves with a high number of phenolic compounds exhibited notable antioxidant activity (Li et al., 2017). 


\section{- Antiviral effect}

Mentha piperita extract has antiviral activity against influenza A, herpes simplex virus, vaccinia virus, and human immunodeficiency virus-1 (HIV-1). It suppresses NO, TNF-a, IL-6, and PGE2 production in macrophages, suggesting a linked pathway in viral infections. RSV infections are known to induce TNF-a secretion, which can exacerbate illness and cause significant weight loss ( $\mathrm{Li}$ et al., 2017).

\subsection{Pepper (Capsicum frutescens L., Capsicum baccatum L. Capsicum аппиит L.)}

The five major species are Capsicum baccatum, Capsicum pubescens, Capsicum frutescens, Capsicum chinense and Capsicum annuum. Peppers of the Capsicum genus contain more than 200 varieties. The fruits differ widely in scale, form, taste and sensory heat.

\section{- Immunomodulatory effect}

Capsaicin is the active constituent of red pepper exhibiting pharmacological and physiological impacts. The red pepper oil supplementation improved the growth, immunity indices and antioxidant activity and reduced lipid peroxidation. The addition of pepper improves the feed consumption because it arouses appetite and recovers the digestive enzyme exudation and augments the body weight.

\section{- Anti-inflammatory effects}

The active ingredient capsaicin is responsible for anti-inflammatory properties of $C$. baccatum. There is a significant reduction of oedema produced through carrageenan-induced paw oedema trial meant for estimation and valuation of anti-inflammatory drugs and amelioration through herbal remedies. Carotenoids are potentially significant as beneficial measure in inflammation and pain. The $\alpha$ - and $\beta$-carotene are peppers carotenoids reducing molecules concerned in the process of inflammation (HernándezOrtega et al., 2012). The extracts of C. baccatum and C. annum show significant anti-inflammatory effect in carrageenan-induced pleurisy model of mice owing to its flavonoid and phenol contents. Capsaicin exhibits anti-inflammatory properties by inhibiting pro-inflammatory mediators like IL-6, TNF-alfa, PGE2 and nitric oxide production. Also, ascorbic acid and capsaicinoids hinder the inflammation progression and making it probable drug candidate against the pathological inflammation (Zimmer et al., 2012).

\section{- Antioxidant effect}

All the peppers have noteworthy antioxidant potency which is measured by DPPH scavenging assay. Pepper extracts had variable scavenging capacity attributed to the amount of $\beta$-cryptoxanthin and $\beta$-carotene contents present. The yellow fraction of carotenoids exhibit significant antioxidant activity (Hernández-Ortega et al., 2012). Nutritionally, C. annum oil contains natural antioxidants such as vitamin C, flavonoids, carotenoids and polyphenols adding flavour and fragrance. Intake of natural foods showed a promising effect in declining the risk of serious health problems because of their antioxidant activities. The pepper contains bioactive compounds like capsaicinoids, flavonoids and vitamins (A, C and E) exhibits many pharmacological effects including antioxidant activity. Red pepper enhances the amino acids, such as cysteine or methionine absorption thus increasing the antioxidative state and health status (Reda et al., 2020).

\subsection{Star anise (Illicium verum Hook. f.)}

It is an evergreen aromatic tree with purple-red flowers and anise-scented star-shaped fruit. It is an important traditional Chinese medicine and spice. It is used in phytotherapy, aromatization of cosmetics and food.

\section{- Anti-inflammatory effect}

The anti-inflammatory activities of $I$. verum are due to presence of shikimic acid and flavonoid quercetin. I. verum extracts exert antiinflammatory effects by suppression of expression of proinflammatory cytokines, TNF-a/IFNg-induced chemokines and adhesion molecules. It also causes obstruction of STAT1, NF-kB, MAPK and Akt activation, proving its usefulness as emerging beneficial drugs for inflammatory conditions (Sung et al., 2012).

\section{- Antioxidant effect}

The essential oils of $I$. verum extracts showed antioxidant activities using DPPH-scavenging and $\beta$-carotene or linoleic acid assays (Aly et al., 2016). The antioxidant properties of the ethanol extracts were assessed using the total equivalent antioxidant capacity, 1,1diphenyl-2-picryhydrazyl (DPPH) radical scavenging effect and reducing power assay. The total amount of phenolic and flavonoid content was also determined. The ethyl acetate fractions have higher phenolics and flavonoids than other extracts with remarkable antioxidant effects (Patra et al., 2020).

\section{- Antiviral effect}

Studies indicate that it is used for the treatment of flu, respiratory tract blockage, lung swelling, bronchitis and whooping cough. The essential oil trans-anethol shows effects like aromatic, antiseptic, antispasmodic and stimulant which serve as crucial elements showing anti-viral activities. Along with essential oils of $I$. verum, plants like Matricaria recutita, Leptospermum scoparium and Melaleuca alternifolia, immensely are potentiated to prevent the infectious capacity of acyclovir-resistant and HSV-sensitive stains, proving its antiviral potential (Asif et al., 2010). I. verum fruits possesses intermediates like shikimic acid serving as a source for synthesis and production of oseltamivir commercially which is effective in seasonal influenza virus types A and B, avian influenza virus $\mathrm{H} 5 \mathrm{~N} 1$ and human influenza virus $\mathrm{H}_{1} \mathrm{~N}_{1}$ having swine origin.

\subsection{Ajwain (Trachyspermum ammi (L.) Sprague ex Turrill)}

It a highly worthy, annual, aromatic and herbaceous plant with a striate stem. The seeds are oval in outline with a ridged appearance. The fruits reveal very pungent taste producing a strong aromatic odour resembling that of thyme.

\section{- Immunomodulatory effect}

The immunomodulation property of ajwain is primarily contributed by thymol and carvacrol. Ajwain seeds can modulate $\mathrm{T}$ cell responses, particularly in alleviating inflamed lung airway in asthmatic cases. Carvacrol balance shifts the immune response from the Th2 type back toward the Th1bydecreasing TNF- $\alpha$, IL-17, IL-4, IL-1 $\beta$, and TGF- $\beta$ cytokine expression and increasing IFN- $\gamma$ 
and FOXP3 expression. Ajwain oil is used in respiratory ailments to deliver its effects through immunomodulation. Thymol stimulates peripheral blood mononuclear cell (PBMC) or lymphocyte proliferation increasing the memory/activated CD8 alpha $+\mathrm{T}$ cell subsets with significant roles in innate immune responses and formation of antibodies (Zarshenas et al., 2014).

\section{- Anti-inflammatory effect}

Ajwain exhibits active anti-inflammatory effects due to terpenes, glycosides and sterols (Qureshi and Kumar, 2010). The extracts of Ajwain showed an inhibitory effect on carrageenan induced oedema on rat model for use of this herb in treatment of inflammatory disease. The marked anti-inflammatory activity of the extracts against acute and subacute inflammation suggests that their activity may occur via inhibition of prostaglandin synthatase.

\section{- Antioxidant effect}

The essential oil produced from Ajwain contains phenols, thymol, etc., which act as reducing agents, hydrogen donators and singlet oxygen quenchers. A positive relationship exists between total phenols and their antioxidants activity in many plant species. The essential oil of ajwain reacts with the free radicals, donated electrons to terminate the chain reaction of oxidation (Chatterjee et al., 2013).

\subsection{Black pepper (Piper nigrum L.)}

Black pepper is a perennial climbing vine. This hot and pungent spice from its fruits, is known as peppercorns. The essential oil obtained from ground black pepper has the aromatic flavour of Capsicum peppers but not the pungency. Black pepper is the most pungent and flavorful of all types of peppers and is available as whole or cracked peppercorns or ground into powder referred to as 'black gold' (Srinivasan, 2007).

\section{- Immunomodulatory effect}

Black pepper boosts the number and efficiency of white blood cells by augmenting strong defence against invading cancer cells and microbes. Piperine-IIa from P. nigrum showed galacturonic acid, galactose, arabinose, and rhamnose monosaccharide composition with purified anti-complementary polysaccharides.

\section{- Anti-inflammatory effect}

The active principle, piperine present in black pepper significantly inhibited the making of two dynamic proinflammatory mediators, i.e., IL6 and $\mathrm{PGE}_{2}$, in IL1 $\beta$-stimulated human FLS. The inhibition of production of $\mathrm{PGE}_{2}$ is important due to its central role in triggering pain (Majumdar et al., 1990). Piperine showed a significant inhibition of increase in oedema volume in a carragenin induced test. Piperine acted significantly on early acute changes in inflammatory process (Singh et al., 2008).

\section{- Antioxidant effect}

Black pepper is an excellent source of real antioxidants with higher quantities of polyphenols, essential oil and oleoresins. The presence of bioactive ingredients in black pepper amends oxidative stress (Mittal and Gupta, 2000) through metal chelating, strong hydrogendonating ability and scavenge free radicals. Piperine synergises with antioxidants like curcumin for disease prevention and taking care of ROS (Aggarwal, 2010).

\section{- Anticovid effect}

The chemical constituents of black pepper such as piperdardiine and piperanine are appreciably active against COVID-19 with remedial potentials (Rajagopal et al., 2020).

\subsection{Cinnamon (Cinnamomum verum J.S. Presl.)}

Cinnamon is a bushy evergreen tree. The spice is derived from bark of the tree. The leaves of the tree are thick and oval or lanceolate in shape. The tree produces small yellow or green flowers on panicles and a berry fruit.

\section{- Immunomodulatory effect}

Cinnamon bark has benzaldehyde, cinnamaldehyde, cuminaldehyde showing immune-stimulatory activity by the serum immunoglobulin levels, antibody titer and reductions in neutrophil count. Cinnamon increases serum immunoglobulin levels. It increases both cell mediated and humoral immunity. Cinnamaldehyde can act as a strong regulator of monocyte/macrophage-mediated immune responses by inhibition of PI3K, PDK1 and NF- $\kappa B$ activation of signalling components (Kwon et al., 2010).

\section{- Anti-inflammatory effect}

The anti-inflammatory action through 22-hydroxycinnamaldehyde isolated from Cinnamon bark inhibited the nitric oxide production by inhibiting the NF- $\kappa \mathrm{B}$ activation (Lee et al., 2005). The ethanolic extract of Cinnamon showed noteworthy anti-inflammatory effects by dropping the activation of Src/spleen-tyrosine-kinase-mediated NF-אB (Yu and Yang, 2012). Cinnamon have shown anti-inflammatory effects by depressing the expression of inducible cyclooxygenase2 (COX-2), nitric oxide (NO) production, nitric oxide synthesis (iNOS). Also, cinnamon reduces the lipopolysaccharide-induced tumor necrosis factor- $\alpha$ levels (Hong et al., 2012).

\section{- Antioxidant effect}

The extracts of cinnamon exhibit antioxidant activities indicated by cardiac and hepatic antioxidant enzymes. Cinnamon potentially exerts superoxide-dismutase- (SOD-) like activity by hindering pyrogallol autoxidation. The phenolics in cinnamon are active against nitric oxide, hydrogen peroxide, lipid peroxide free radicals (Aravind et al., 2012).

\subsection{Cardamom (Alpinia cardamomum (L.) Roxb.; Amomum cardamomum L.)}

Cardamom is a perennial bush. The aerial pseudostem is made of leaf sheaths. It has a large tuberous underground rhizome and long, dark green leaves. These bear the seed pods. The flowers are green with a white purple-veined tip. Cardamom is popularly known as 'queen of spices'.

\section{- Immunomodulatory effect}

Enzyme-linked immunosorbent assay recognized that cardamom significantly suppresses $\mathrm{T}$ helper (Th) 1 cytokine release by splenocytes but $\mathrm{Th} 2$ cytokine release by splenocytes is meaningfully boosted. The immunomodulatory effects of macrophages in 
production of pro-inflammatory cytokines IL- 6 and TNF- $\alpha$ is seen in response to extracts of cardamom (Majdalawieh and Carr, 2010).

\section{- Anti-inflammatory effect}

The cardamom extracts significantly decreased the secretion of IL-1 $\beta$, and IL- 8 by lipopolysaccharide-stimulated macrophages. The antiinflammatory activity is due to inhibition of the NF- $\mathrm{KB}$ signaling pathway. Cardamom oil has anti-inflammatory effect comparable with diclofenac in carrageenan induced rat paw edema reduction (Sapra et al., 2000).

\section{- Antioxidant effect}

Cardamom exerts antioxidant protection through its ability to activate the antioxidant enzymes. The antioxidant enzyme actions were enhanced and GSH content was markedly reinstated in rats fed a fat diet with cardamom. Cardamom partly countered upsurge in lipid conjugated dienes and hydroperoxides which are the primary products of lipid peroxidation (Beddows et al., 2000).

\subsection{Mustard (Brassica nigra (L.) Koch)}

Mustard is a herbaceous annual plant. All of the three mustards, Sinapis hirta (white or yellow mustard), Brassica juncea (brown or Indian mustard) and Brassica nigra (black mustard) produce small mustard seeds used as a spice.

\section{- Immunomodulatory effect}

Mustard contains iron, manganese, copper improving the body's ability to fight disease. Brassica nigra prevented the influence of pyrogallol on immunological parameters and antioxidant parameters due to fatty acids present stimulating the immune system by changing eicosanoids production (Casale and Stokes, 2008).

\section{- Anti-inflammatory effect}

The extracts significantly reduced myeloperoxidase activity of the inflammation, and inhibited the mRNA and protein levels of IL-6 and TNF- $\alpha$. Brassica juncea was effective anti-inflammatory drugs as it significantly depressed the nitric oxide (NO) production and nitrite synthesis. This nitrite and nitric oxide inhibition clarify the anti-inflammatory activities of mustard leaf (Kim et al., 2011). Mustard seeds are high in selenium and magnesium which proves it as exclusive anti-inflammatory agent (Tian and Deng, 2020).

\section{- Antioxidant effect}

Mustard is rich in vitamin A, vitamin C, phenolic compounds, glucosinolates, and other compounds with antioxidant properties mediated by the content of polyphenols and flavonoids (Park et al., 2017). The protective effect of extract of mustard leaf (Brassica campestris) on chromosomal damage and oxidative stress induced by $\gamma$-radiation was ameliorated by minerals increasing antioxidants activity catalysing the oxidative chain reactions (Alam et al., 2013).

\subsection{Fennel (Foeniculum vulgare Mill)}

Fennel is a flowering hardy, perennial herb with yellow flowers and feathery leaves. The herb type grows 3-5 feet tall with fine textured foliage. Stems, leaves and seeds of this type of fennel are harvested and used. Fennel is a versatile plant used both for cooking and decorative use.

\section{- Immunomodulatory effect}

The extract of the Foeniculum vulgare increases the blood cells like RBCs, WBCs and lymphocytes and haemoglobin concentration but decreases the average platelets and proves the efficacy in modulating the immune system (Mansouri et al., 2015).

\section{- Anti-inflammatory effect}

Methanol extract of $F$. vulgare also inhibits ear-edema induced by arachidonic acid suggesting its action on both the cyclooxygenase and lipoxygenase pathways (Choi and Hwang, 2004).

\section{- Antioxidant effect}

Fennel is a wonderful source of natural antioxidants (Shahat et al., 2011). The phenolic and flavonoid present in fennel exhibited radical scavenging activity and antioxidant activities as per the anionic radical absorption tests and metal chelating activity.

\section{Use of spices in kadha}

Kadha can be defined as a traditional, homemade, aromatic drink with many medicinal effects, thus has a healing effect on the body. Different medicinal herbs and spices are commonly used to prepare kadha. From ancient age, it has been in use in India but currently it has come to the picture with a significant role of boosting body immunity due to the corona pandemic. In addition to the immunostimulant effect, kadha also exerts body relaxation, antipyretic, enhancement of skin quality, wellness of stomach, preventing cold, cough, flu, sore throat, etc. (Wajpeyi, 2020). Kadha is a rich source of antioxidants. Kadha, the ayurvedic drink is prepared by boiling different herbs and spices including tulsi (basil), dalchini (cinnamon), kalimirch (black pepper), shunthi (dry ginger), turmeric, clove, etc., in water. These herbs and spices contain several immunity-boosting active ingredients and other healing compounds. Unlike drugs, these natural sources have no detrimental side effect so it can be used across all ages of people. This kadha also detoxifies the body and improves digestion. Due to the immunity enhancing capacity this kadha should be used as a measure for self-care during COVID-19 (Chintale, 2020).

\section{Potentials and limitations of spices}

The health benefits obtained from spices are wide. They contribute to make up for nutritional supplements, help boost the immune system and help maintain blood sugar and blood cholesterol levels. Spices also have anti-inflammatory and antioxidant properties, and they help prevent various bacterial, viral, fungal and protozoal infections. As an antioxidant spices help increase oxygenation and circulation in the body. Thus, they help restore correct functioning of the system. Spices contain many vitamins and minerals, which provide some of the most necessary elements for leading a healthy life (Srinivasan, 2005).

Generally, spices have no major side effects. But allergic reactions are seen in people after eating of some spices. These allergic reactions include, but are not limited to, occupational contact dermatitis, bronchial asthma, rhinitis and anaphylactic shock. Additionally, certain spices can react with certain medications and cause complications such as thinning of the blood, and formation of haemorrhoids. Sometimes certain spices if consumed in excess may cause gastroenteritis. However, limitations are rarely seen and the benefits of spices are certainly more significant than side effects (Embuscado, 2015). 

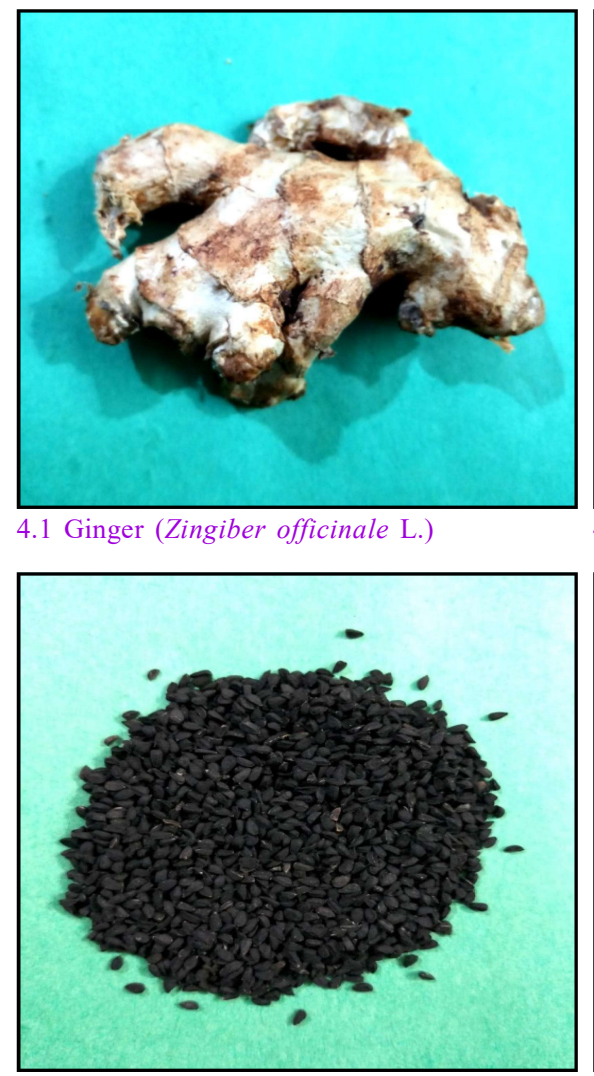

4.4 Black cumin (Nigella sativa L.)

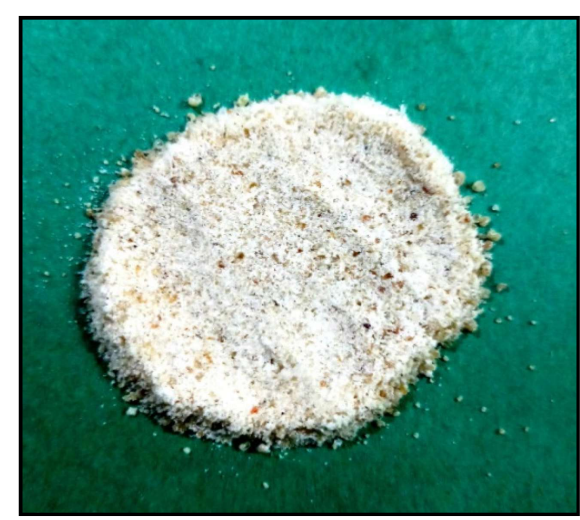

4.7 Asafoetida (Ferulaassa-foetida L.)

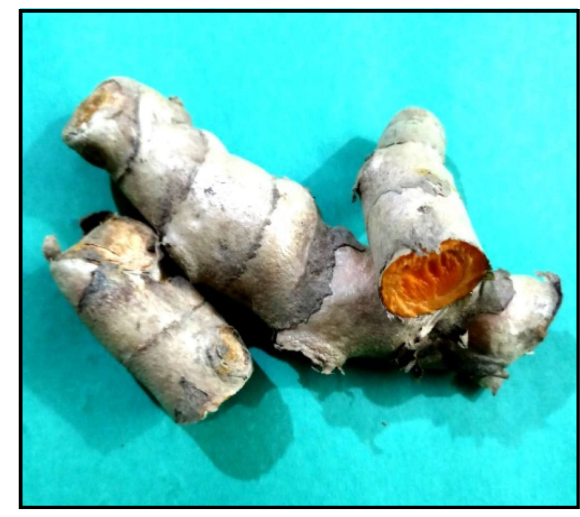

4.10 Turmeric (Curcuma longa L.)

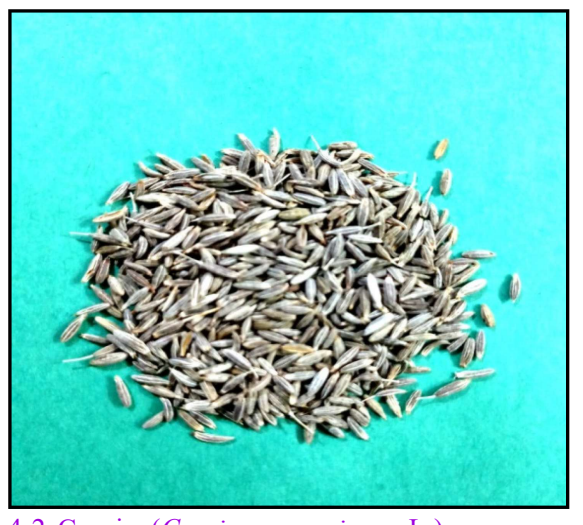

4.2 Cumin (Cuminum cyminum L.)

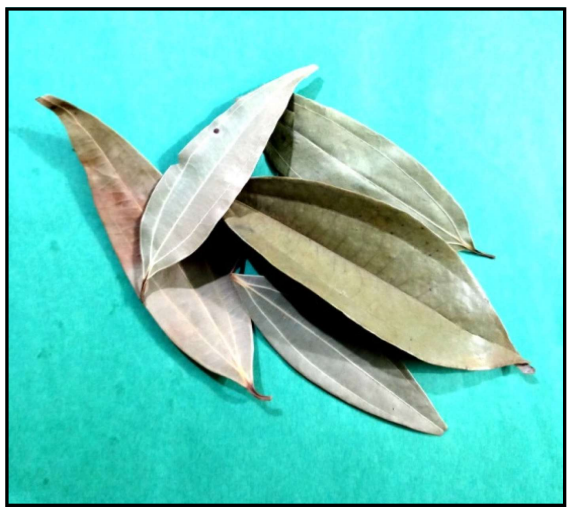

4.5 Bay leaves (Cinnamomum tamala (Buch. -Ham.) 4.6 Fenugreek (Trigonella foenum-graecum L.) T.Nees \& C.H.Eberm.)

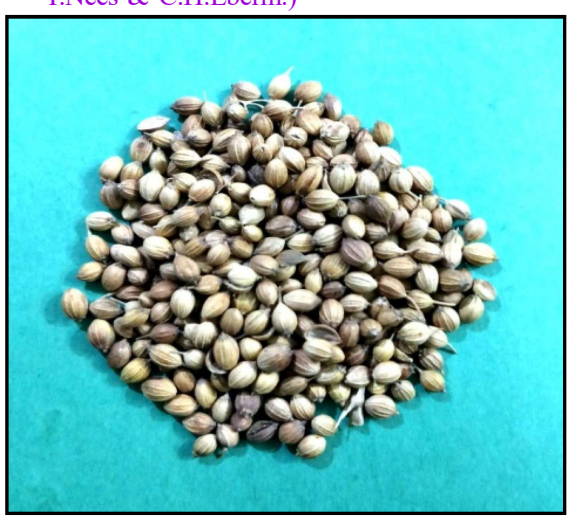

4.8 Coriander (Coriandrum sativum L.)

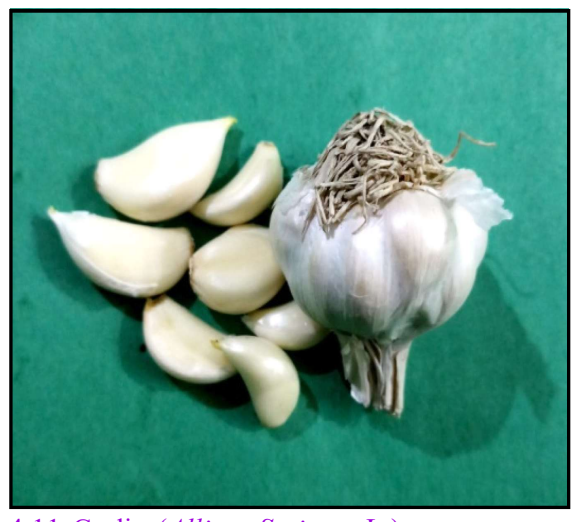

4.11 Garlic (Allium Sativum L.)

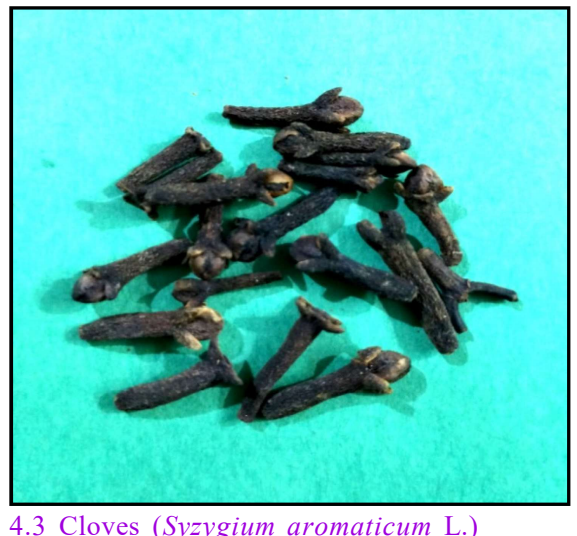

4.3 Cloves (Syzygium aromaticum L.)
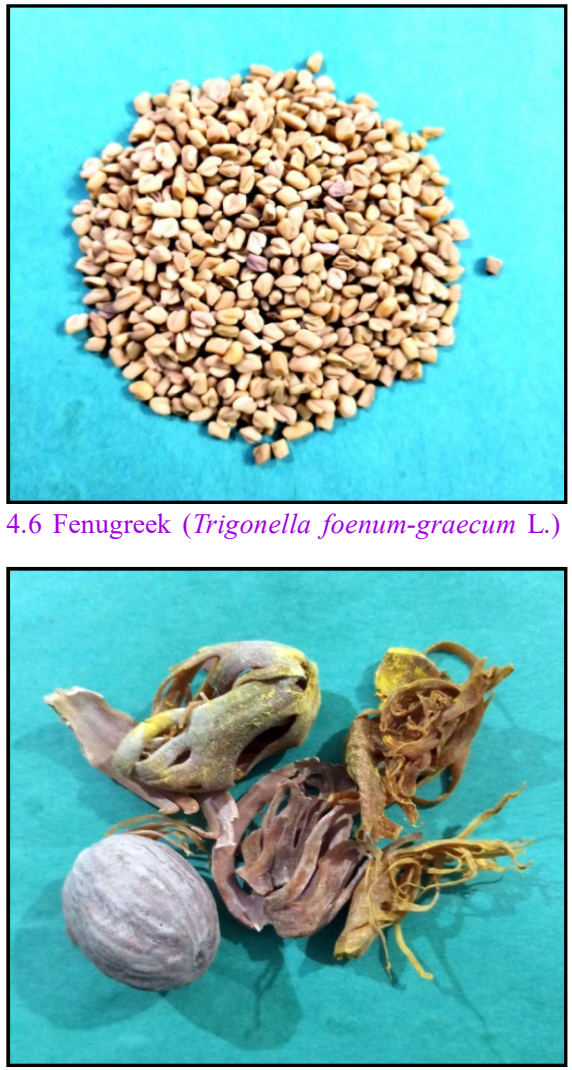

4.9 Nutmeg and Mace (Myristica fragrans Houtt.)

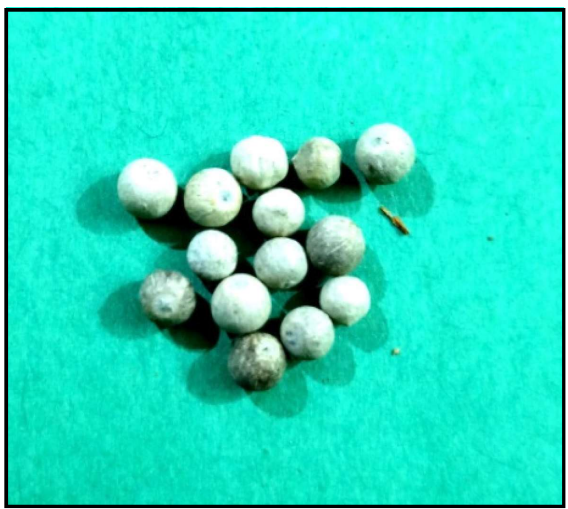

4.12 Allspice (Pimentaofficinalis (L.) Merr.) 

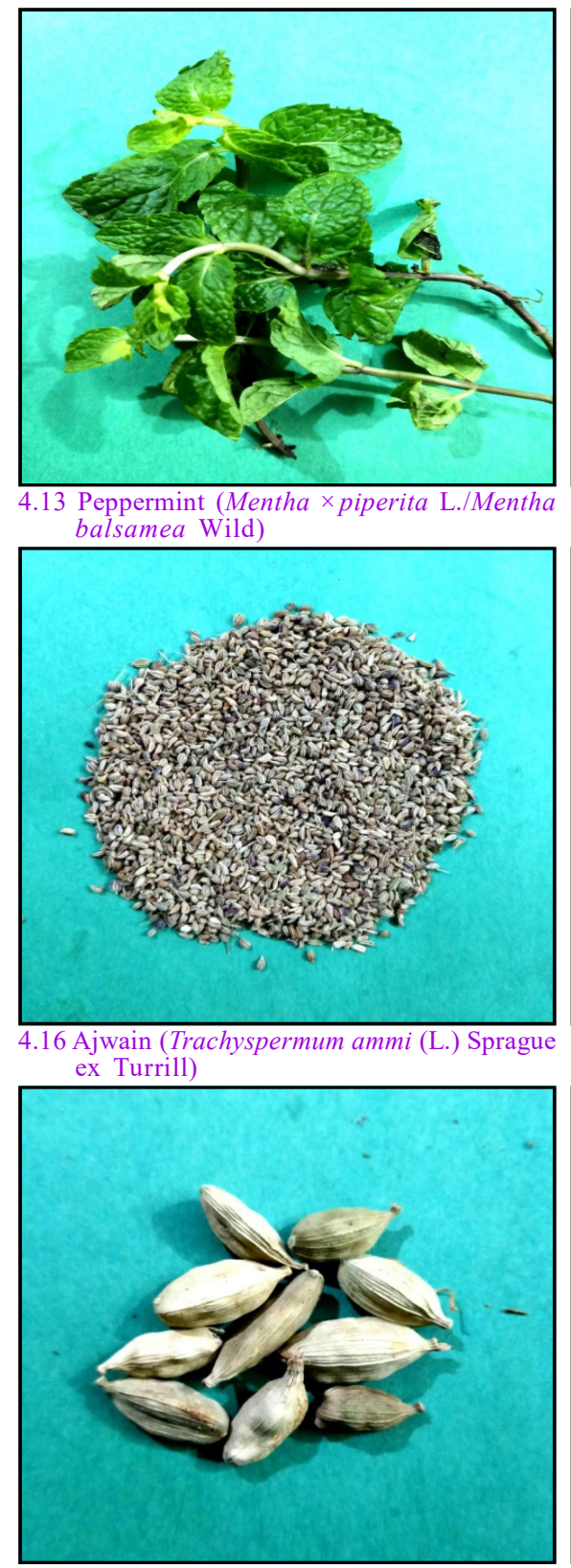

4.19 Cardamom (Alpinia cardamomum
Roxb.; Amomum cardamomum L.)

\section{Conclusion}

Natural or herbal anti-COVID-19 drug mixtures can be developed by the proper blend of spices against the current viral infection, COVID-19. Combinations of right herbs in a formula and an appropriate dosage may be a promising alternative therapeutic and preventive measure. The spice alone or as mixtures, with potential effects of SARS-CoV-2 should be tested in the future. Convenient and more stable drugs using bioactive of these spices such as inhaler, herbal tonic mukhvas, herbal lozenges, herbal drug patches can be developed for immunity. These spices when used will certainly enhance immunity and helps to combat many stuffs about

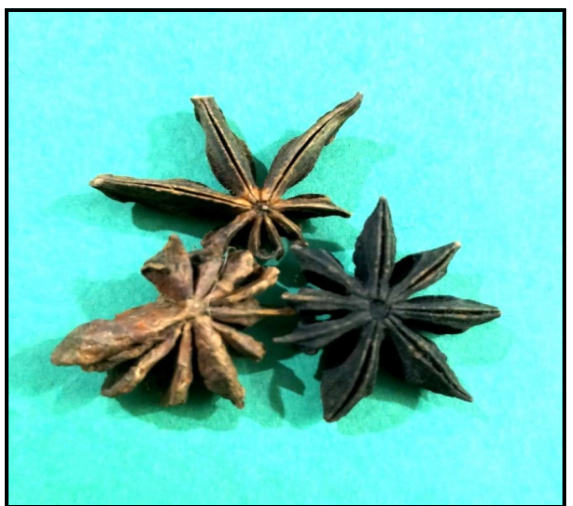

4.15 Star anise (Illicium verum Hook. f.)

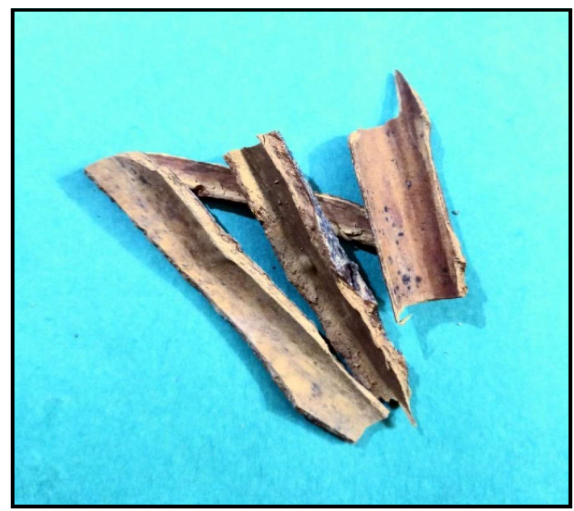

4.18 Cinnamon (Cinnamomum verum J.S. Presl.)

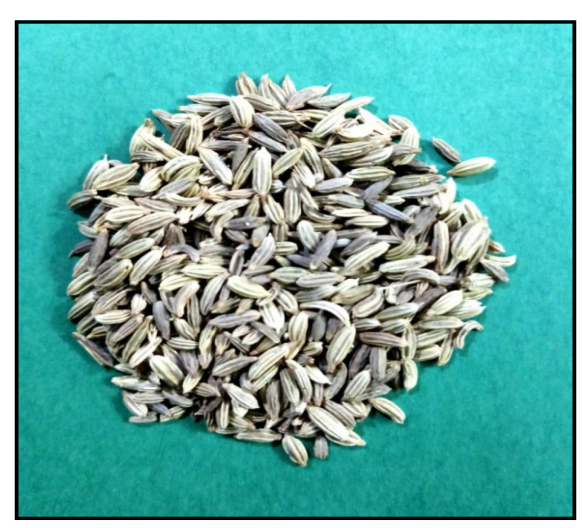

4.21 Fennel (Foeniculum vulgare Mill) wellbeing. Proper education on the health advantage of these spices in everyday cooking must be encouraged.

The therapeutic effectiveness of these spices should be assessed against COVID-19 and drug discovery through these spices will assist in the battle against COVID-19 infection. However, the product bioavailability with anti-SARS-CoV-2 in addition to their utility and protection is to be scientifically validated. Although the exact molecular mechanisms related to spices and immunity associated with them are not entirely stated, our findings conclude that spices have properties to fight COVID-19. More rigorous research is needed to regulate and validate these findings. 


\section{Conflict of interest}

The authors declare that there are no conflicts of interest relevant to this article.

\section{References}

Adel, M.; Safari, R.; Pourgholam, R.; Zorriehzahra, J. and Esteban, M. Á. (2015) Dietary peppermint (Mentha piperita) extracts promote growth performance and increase the main humoral immune parameters (both at mucosal and systemic level) of Caspian brown trout (Salmo trutta caspius Kessler, 1877). Fish and Shellfish Immunology, 47(1):623-629.

Aggarwal, B. B. (2010). Targeting inflammation-induced obesity and metabolic diseases by curcumin and other nutraceuticals. Annu. Rev. Nutr., 30:173-199.

Ahmad, A.; Husain, A.; Mujeeb, M.; Khan, S.A.; Najmi, A.K.; Siddique, N.A.; Damanhouri, Z.A. and Anwar, F. (2013). A review on therapeutic potential of Nigella sativa: A miracle herb. Asian Pac. J. Trop. Biomed., 3:337-352.

Alam, M.N.; Bristi, N.J. and Rafifiquzzaman, M. (2013). Review on in vivo and in vitro methods evaluation of antioxidant activity. Saudi Pharmaceutical., 21(2):143-152.

Ali, B.H.; Blunden, G; Tanira, M.O. and Nemmar, A. (2004). Some phytochemical, pharmacological and toxicological properties of ginger (Zingiber officinale Roscoe): A review of recent research. Food Chem Toxicol., 46:409-420.

Al-Snafi A.E. (2016). The pharmacological activities of Cuminum cyminum: A review. IOSR Journal of Pharmacy, 6:46-65.

Aly, S.E.; Sabry, B.A.; Shaheen, M.S. and Hathout, A.S. (2016). Assessment of antimycotoxigenic and antioxidant activity of star anise (Illicium verum) in vitro. Journal of the Saudi Society of Agricultural Sciences, 15(1):20-27.

Amalraj, A. and Gopi, S. (2016). Biological activities and medicinal properties of Asafoetida: A review. J. Tradit. Complement. Med., 7(3):347-359. doi:10.1016/j.jtcme.2016.11.004

Amri, M. and Touilboukoffa, C. (2016). In vitro anti-hydatic and immunomodulatory effects of ginger and gingerol. Asian Pacific Journal of Tropical Medicine, 9(8):749-756. https://doi.org/ 10.1016/j.apjtm.2016.06.013

Aravind, R.; Aneesh, T.; Bindu, A. and Bindu, K. (2012). Estimation of phenolics and evaluation of antioxidant activity of Cinnamomum malabatrum (Burm. F). Blume. Asian J. Res. Chem., 5(5):628-632.

Asif, M.; Saleem, M.; Saadullah, M.; Yaseen, H.S. and Al Zarzour, R. (2020). COVID-19 and therapy with essential oils having antiviral, antiinflammatory, and immunomodulatory properties. Inflammopharmacology, 20(5):1153-1161.

Bagheri, S.M.; Hedesh, S.T.; Mirjalili, A. and Dashti-R, M.H. (2016) Evaluation of anti-inflammatory and some possible mechanisms of antinociceptive effect of Ferula assafoetida oleo gum resin. Journal of Evidence-based Complementary and Alternative Medicine, 21(4):271-276.

Beddows, C.G.; Jagait, C. and Kelly, M.J. (2000). Preservation of alphatocopherol in sunflower oil by herbs and spices. Int. J. Food Sci. Nutr., 51(5):327-339.

Bilen, S. and Bulut, M. (2010). Effects of laurel (Laurus nobilis) on the non-specific immune responses of rainbow trout (Oncorhynchus mykiss, Walbaum). Journal of Animal and Veterinary Advances, 9:1275-1279.
Boskabady, M.H.; Vahedi, N.; Amery, S. and Khakzad, M.R. (2011). The effect of Nigella sativa alone, and in combination with dexamethasone, on tracheal muscle responsiveness and lung inflammation in sulfur mustard exposed guinea pigs. Journal of Ethnopharmacology, 137(2):1028-1034. doi: 10.1016/j.jep.2011.07.030

Capasso, A. (2013). Antioxidant action and therapeutic efficacy of Allium sativum. L. Molecules, 18(1):690-700.

Casale, T.B. and Stokes, J.R. (2008). Immunomodulators for allergic respiratory disorders. J. Allergy Clin. Immunol., 121(2):288-296.

Chahal, K.K.; Dhaiwal, K.; Kumar, A.; Kataria, D. and Singla, N. (2017). Chemical composition of Trachyspermum ammi L. and its biological properties: A review. J. Pharmaco. Phytochem., 9:775-786.

Charles, D.J. (2012). Nutmeg. In: Antioxidant properties of spices, herbs and other sources, Springer, New York, pp:427-434.

Chatterjee, S.; Goswami, N. and Kothari, N. (2013). Evaluation of antioxidant activity of essentialoil from Ajwain (Trachyspermum ammi) seeds. Int. J. Green Pharm., 7:140-144.

Chauhan, P.S.; Satti, N.K.; Suri, K.A.; Amina, M. and Bani, S. (2010). Stimulatory effects of Cuminum cyminum and flavonoid glycoside on cyclosporine: A and restraint stress induced immune-suppression in Swiss albino mice. Chem. Biol. Interact., 185(1):66-72. doi: 10.1016/j.cbi.2010.02.016.

Checker, R.; Chatterjee, S.; Sharma, D.; Gupta, S.; Variyar, P.; Sharma, A. and Poduval, T.B. (2008). Immunomodulatory and radioprotective effects of lignans derived from fresh nutmeg mace (Myristica fragrans) in mammalian splenocytes. International Immunopharmacology, 8(5):661-669.

Chintale, S.G. (2020). In COVID-19 pandemic ayurvedic medicine 'KADHA' although immune booster affects the oropharynx and gastrointestinal system. Am. J. Otolaryngol. Head Neck Surg., 3(6): 1109

Choi, E. and Hwang, J. (2004). Antiinflammatory, analgesic and antioxidant activities of the fruit of Foeniculum vulgare. Fitoterapia, 75(6):557-565.

Clement, F.; Pramod, S.N. and Venkatesh, Y.P. (2010). Identification of the immunomodulatory proteins from garlic (Allium sativum) with the major garlic lectins or agglutinins. International Immunopharmacology, 10(3):316-324.

Dewi, K.; Widyarto, B.; Erawijantari, P.P. and Widowati, W. (2015). In vitro study of Myristica fragrans seed (Nutmeg) ethanolic extract and quercetin compound as anti-inflammatory agent. Int. J. Res. Med. Sci., 3(9):2303-2310.

Dibazar, S.P. and Daneshmandi, S. (2015). Immunomodulatory effects of clove (Syzygium Aromaticum) constituents on macrophages: In vitro evaluations of aqueous and ethanolic components. Journal of Immunotoxicology, 12(2):124-131.

Elmastap, M.; Gulçin, I.; Ipildak, O.; Kufrevioglu, O.; Ýbaoglu, K. and Aboul-Enein, H. (2006). Radical scavenging activity and antioxidant capacity of bay leaf extracts. Journal of the Iranian Chemical Society, 3:258-266.

Elsayed, Y. and Khan, N.A. (2020). Immunity-boosting spices and the novel coronavirus. ACS chemical neuroscience, 12:1696-1698.

Embuscado, M.E. (2015). Spices and herbs: Natural sources of antioxidantsA mini review. Journal of Functional Foods, 18:811-819.

Gong, J.; Fang, K.; Dong, H.; Wang, D.; Hu, M. and Lu, F. (2016). Effect of fenugreek on hyperglycaemia and hyperlipidemia in diabetes and prediabetes: A meta-analysis. Journal of Ethnopharmacology, 194:260-268. 
Guo, X.J. and Thomas, P.G. (2017). New fronts emerge in the influenza cytokine storm. Semin Immunopathol., 39(5):541-550.

Henri, A.F. and Erik, A. (2020). Immunopathogenesis of COVID-19: Summary and possible interventions. Frontiers in immunology, 11:242. doi=10.3389/fimmu.2020.564925.

Hernandez-Ortega, M.; Ortiz-Moreno, A.; Hernandez-Navarro, M.D.; Chamorro-Cevallos, G.; Dorantes-Alvarez, L. and NecoecheaMondragón, H. (2012). Antioxidant, antinociceptive, and antiinflammatory effects of carotenoids extracted from dried pepper (Capsicum annuum L.). Journal of Biomedicine and Biotechnology, pp:524019. doi: 10.1155/2012/524019.

Hong, J.W.; Yang, G.E.; Kim, Y.B.; Eom, S.H.; Lew, J.H. and Kang, H. (2012) Anti-inflammatory activity of cinnamon water extract in vivo and in vitro LPS-induced models. BMC Complement. Alt. Med., 12(1):237-240.

Huang, F.; Li, Y.; Leung, E.L.H.; Liu, X.; Liu, K.; Wang, Q. and Luo, H. (2020) A review of therapeutic agents and Chinese herbal medicines against SARS-COV-2 (COVID-19). Pharmacological Research, pp:104929.

Jaiswal, P.; Kumar, P.; Singh, V.K. and Singh, D.K. (2009). Biological effects of Myristica fragrans. Annual Review of Biomedical Sciences, 11:12

Jayyab, A.A. (2020). Nutritional pharmacology aspects and potentia clinical uses of clove essential oil in the treatment of coronavirus infection and possibility protect from coronavirus (COID19) induced sudden death due the embolism. Journal of Chemical Biology and Pharmaceutical Chemistry, 1(1):14-19

Khan, A.A.; Khan, S.; Khan, U. and Das, K. (2020). The COVID-19 pandemic: A scoping review. Ann. of Phytomed., 9(1):18-26.

Kim, H.; Kim, J.Y.; Kim, H.J.; Kim, D.K.; Jo, H.J.; Han, B.S.; Kim, H.W. and Kim, J.B. (2011). Anticancer activity and quantitative analysis of glucosinolates from green and red leaf mustard. Korean Journal of Food and Nutrition, 24(3):362-366

Kim, S.; Kundu, J. and Shin, Y. (2005). Gingerol inhibits COX-2 expression by blocking the activation of $\mathrm{p} 38$ MAP kinase and NF- $\kappa \mathrm{B}$ in phorbo ester-stimulated mouse skin. Oncogene, 15:2558-2567.

Koshak, A.E. and Koshak, E.A. (2020). Nigella sativa L. as a potential phytotherapy for coronavirus disease 2019: A mini review of in silico studies. Current Therapeutic Research, pp:100602. https:/ /doi.org/10.1016/j.curtheres.2020.100602.

Kozan, E.; Küpeli, E. and Yesilada, E. (2006). Evaluation of some plants used in Turkish folk medicine against parasitic infections for their in vivo anthelmintic activity. Journal of Ethnopharmacology, 108:211-216

Kulyar, M.F.; Li, R.; Mehmood, K.; Waqas, M.; Li, K. and Li, J. (2020) Potential influence of Nigella sativa (Black cumin) in reinforcing immune system: A hope to decelerate the COVID-19 pandemic. Phytomedicine: International Journal of Phytotherapy and Phyto Pharmacology, pp:153277. https://doi.org/10.1016/j.phymed. 2020.153277

Kwon, H.K.; Hwang, J.S. and So, J.S. (2010). Cinnamon extract induces tumor cell death through inhibition of NF5øßB and AP1. BMC Cancer, 10(1):392.

Lang, G. and Buchbauer, G. (2011). A review on recent research results (2008-2010) on essential oils as antimicrobials and antifungals. A review. Flavour and Fragnance Journal, 27(1):13-39. https:// doi.org/10.1002/ffj. 2082 .
Lechien, J.R.; Chiesa-Estomba, C.M.; De Siati, D.R.; Horoi, M.; Le Bon, S.D. and Rodriguez, A. (2020). Olfactory and gustatory dysfunctions as a clinical presentation of mild-to-moderate forms of the coronavirus disease (COVID-19): A multicenter European study. Eur. Arch. Otorhinolaryngol., 277(8):2251-2261. doi: 10.1007/s00405-02005965-1

Lee, K. Y. (2015). A common immunopathogenesis mechanism for infectious diseases: The protein-homeostasis-system hypothesis. Infect Chemother., 47:12-26

Lee, S.H.; Lee, S.Y. and Son, D.J. (2005). Inhibitory effect of 2hydroxycinnamaldehyde on nitric oxide production through inhibition of NF-5ØßB activation in RAW cells. Biochem. Pharmacol., 69(5):91-799.

Li, Y.; Liu, Y.; Ma, A.; Bao, Y.; Wang, M. and Sun, Z. (2017). In vitro antiviral, anti-inflammatory, and antioxidant activities of the ethanol extract of Mentha piperita L. Food Science and Biotechnology, 26(6): 1675-1683

Majdalawieh, A.F. and Carr, R.I. (2010). In vitro investigation of the potential immunomodulatory and anti-cancer activities of black pepper (Piper nigrum) and cardamom (Elettaria cardamomum). J. Med. Food, 13(2):371-381.

Majdalawieh, A.F. and Fayyad, M.W. (2015). Immunomodulatory and anti-inflammatory action of Nigella sativa and thymoquinone: A comprehensive review. Int. Immunopharmacol., 28(1):295-304. doi: $10.1016 /$ j.intimp.2015.06.023.

Mandal, S. and Mandal, M. (2015). Coriander (Coriandrum sativum L.) essential oil: Chemistry and biological activity. Asian Pacific Journal of Tropical Biomedicine, 5(6):421-428.

Mansouri, E.; Kooti, W.; Bazvand, M.; Boroon, M. G.; Amirzargar, A.; Afrisham, R.; Damoon Ashtary-Larky, M. R. and Jalali, N. (2015). The effect of hydro-alcoholic extract of Foeniculum vulgare Mill on leukocytes and hematological tests in male rats. Jundishapur J. Nat. Pharm. Prod., 10(1):183-186.

Mao, Q.Q.; Xu, X.Y. and Cao, S.Y. (2019). Bioactive compounds and bioactivities of ginger (Zingiber officinale Roscoe). Foods, 8:185

Martino, L.; De Feo, N.; Fratianni, F. and Nazzaro, F. (2009). Chemistry, antioxidant, antibacterial and antifungal activities of volatile oils and their components. Nat. Prod. Commu., 4:1741-1750.

McKay, D.L. and Blumberg, J.B. (2006). A review of the bioactivity and potential health benefits of peppermint tea (Mentha piperita L.). Phytotherapy Research: An International Journal Devoted to Pharmacological and Toxicological Evaluation of Natural Product Derivatives, 20(8):619-633.

Mittal, R. and Gupta, R.L. (2000). In vitro antioxidant activity of piperine. Exp. Clin. Pharmacol., 22:271-274.

Moutia, M.; Habti, N. and Badou, A. (2018). In vitro and in vivo immunomodulator activities of Allium sativum. Evidence-Based Complementary and Alternative Medicine. pp:4984659. https:// doi.org/10.1155/2018/4984659

Mujumdar, A.M., Dhuley, J.N. and Deshmukh, V.K. (1990). Anti-inflammatory activity of piperine. Jpn. J. Med. Sci. Biol., 43(3):95-100.

Naidu, M.; Shyamala, B.N.; Naik, J.; Sulochanamma, G. and Madhava, P. (2011). Chemical composition and antioxidant activity of the husk and endosperm of fenugreek seeds. LWT-Food Science and Technology, 2:451-456.

Olajide, O.A.; Ajayi, F.F.; Ekhelar, A.I.; Awe, S.O.; Makinde, J.M. and Alada, A.A. (1999). Biological effects of Myristica fragrans (nutmeg) extract. Phytotherapy Research, 13(4):344-345.

Park, E.J. and Pizzuto, J.M. (2002). Botanicals in cancer chemoprevention. Cancer Metast Rev., 21:231-255. 
Park, S.Y.; Jang, H.L.; Lee, J.H.; Choi, Y.; Kim, H.; Hwang, J.; Seo, D.; Kim, S. and Nam, J.S. (2017). Changes in the phenolic compounds and antioxidant activities of mustard leaf (Brassica juncea) kimchi extracts during different fermentation periods. J. Food Sci. Biotech., 26(1):105-112.

Patra, J.K.; Das, G.; Bose, S.; Banerjee, S.; Vishnuprasad, C.N.; del Pilar Rodriguez Torres, M. and Shin, H.S. (2020). Star anise (Illicium verum): Chemical compounds, antiviral properties, and clinical relevance. Phytotherapy Research, 34(6):1248-1267.

Qureshi, A.A. and Kumar, K.E. (2010). Phytochemical constituents and pharmacological activities of Trachyspermum ammi. Plant Archives, 10(2):955-959.

Rajagopal, K., Byran, G., Jupudi, S. and Vadivelan, R. (2020). Activity of phytochemical constituents of black pepper, ginger, and garlic against coronavirus (COVID-19): An in silico approach. Int. J. Health Alld. Sci., 9(5):43-50.

Rajeshwari, C.U.; Vinay Kumar, A.V. and Andallu, B. (2011). Therapeutic potential of Ajwain (Trachyspermum ammi L.) Seeds: Nuts and Seeds. In: Health Prevention, Elsevier.

Reda, F.M.; Alagawany, M.; Mahmoud, H.K.; Mahgoub, S.A. and EInesr, S.S. (2020). Use of red pepper oil in quail diets and its effect on performance, carcass measurements, intestinal microbiota, antioxidant indices, immunity and blood constituents. Animal, 14(5): $1025-1033$.

Reuter, J.; Huyke, C.; Casetti, F.; Theek, C.; Frank, U.; Augustin, M. and Schempp, C. (2008). Anti-inflammatory potential of a lipolotion containing coriander oil in the ultraviolet erythema test. Journa der Deutschen Dermatologischen Gesellschaft, 6(10):847-851.

Rothan, H.A. and Byrareddy, S.N. (2020). The epidemiology and pathogenesis of coronavirus disease (COVID-19) outbreak. J Autoimmun., 109:102433. doi: 10.1016/j.jaut.2020.102433

Sapra, B.; Gupta, S. and Tiwary, A.K. (2000). Role of volatile oil pretreatment and skin cholesterol on permeation of ion-paired diclofenac sodium. Indian J. Exp. Biol., 38(9):895-900.

Shahat, A.A.; Ibrahim, A.Y. and Hendawy, S.F. (2011). Chemica composition, antimicrobial and antioxidant activities of essentia oils from organically cultivated fennel cultivars. Molecules, 16(2):1366-1377.

Shi, Y.; Wang, Y. and Shao, C. (2020). COVID-19 infection: The perspectives on immune responses. Cell Death Differ., 27:1451-1454. https:/ /doi.org/10.1038/s41418-020-0530-3

Singh, G.; Kapoor, I.P.S.; Singh, P.; De Heluani, C.S.; De Lampasona, M.P. and Catalan, C.A. (2010). Comparative study of chemical composition and antioxidant activity of fresh and dry rhizomes of turmeric (Curcuma longa Linn.). Food and Chemical Toxicology, 48(4): 1026-1031.

Singh, R.; Singh, S.; Saini, B.S. and Rao, H.S. (2008). In vitro antioxidan activity of pet ether extract of black pepper. Indian J. Pharmacol., 40(4): 147-151

Singletary, K. (2016). Coriander: Overview of potential health benefits. Nutrition Today, 51(3):151-161.

Smith, A. and Brennessel, J. (1994). Cytomegalovirus. Infect. Dis. Clin. North Am., 8:427-438.

Soni, V.K.; Mehta, A.; Ratre, Y.K.; Tiwari, A.K.; Amit, A., Singh; R.P. and Vishvakarma, N.K. (2020). Curcumin, a traditional spice component, can hold the promise against COVID-19? European Journal of Pharmacology, 886:173551.
Srinivasan, K. (2005). Role of spices beyond food flavoring: Nutraceuticals with multiple health effects. Food Reviews International, 21(2):167-188.

Srinivasan, K. (2006). Fenugreek (Trigonella foenum-graecum): A review of health beneficial physiological effects. Food Reviews International, 2:203-224.

Srinivasan, K. (2007). Black pepper and its pungent principle-piperine: A review of diverse physiological effects. Crit. Rev. Food Sci. Nutr., 47(8):735-748.

Srivastava, R.M.; Singh, S.; Dubey, S.K.; Misra, K. and Khar, A. (2011). Immunomodulatory and therapeutic activity of curcumin. International Immunopharmacology, 11(3):331-341.

Sung, Y.Y.; Kim, Y.S. and Kim, H.K. (2012). Illicium verum extract inhibits TNF- $\alpha$-and IFN- $\gamma$-induced expression of chemokines and cytokines in human keratinocytes. Journal of Ethnopharmacology, 144(1): 182-189.

Tian, Y. and Deng, F. (2020). Phytochemistry and biological activity of mustard (Brassica juncea): A review. Cyta - J. Food, 18(1):704-718.

Upadhyay, G.; Khosala, S.; Kosuru, R. and Singh, S. (2016). Anxiolytic, antidepressant, and anti-stress activities of the aqueous extract of Cinnamomum tamala Nees and Eberm in rats. Indian J. Pharmacol., 48(5):555-561.

Venkatesh, Y. P. (2018). Immunomodulatory attributes of aged garlic extract and its components. In: Immunology, Academic Press, pp:203-224.

Wajpeyi, S.M. (2020). AYUSH ministry's health advisory in COVID-19: A critical review. International Journal of Research in Pharmaceutical Sciences, 11(SPL)(1):201-207.

Yu, T. and Yang, W.S. (2012). The ability of an ethanol extract of Cinnamomum cassia to inhibit Src and spleen tyrosine kinase activity contributes to its anti-inflammatory action. J. Ethnopharmacol., 139(2):566-573.

Zahedipour, F.; Hosseini, S. A.; Sathyapalan, T.; Majeed, M.; Jamialahmadi, T.; AIRasadi, K.; Banach, M. and Sahebkar, A. (2020). Potential effects of curcumin in the treatment of COVID-19 infection. Phytother. Res. 34(11):2911-2920. doi: 10.1002/ptr.6738. Advance online publication.

Zarshenas, M. M.; Moein, M.; Samani, S. M. and Petramfar, P. (2014). An overview on Ajwain (Trachyspermum ammi) pharmacological effects: Modern and traditional. J. Nat. Rem., 14:98-105.

Zhang, L. and Lokeshwar, B. (2012). Medicinal properties of the Jamaican pepper plant Pimenta dioica and Allspice. Current Drug Targets, 13(14):1900-1906.

Zhang, Y. J.; Gan, R. Y.; Li, S.; Zhou, Y.; Li, A.N.; Xu, D.P. and Li, H.B. (2015). Antioxidant phytochemicals for the prevention and treatment of chronic diseases. Molecules, 20(12):21138-21156. doi: 10.3390/ molecules201219753.

Zhu, M.; Wong, P.Y. and Li, R.C. (1999). Effect of oral administration of fennel (Foeniculum vulgare) on ciprofloxacin absorption and disposition in the rat. J. Pharm. Pharmacol., 51(12):1391-1396.

Zimmer, A.R.; Leonardi, B.; Miron, D.; Schapoval, E.; de Oliveira, J.R. and Gosmann, G. (2012). Antioxidant and anti-inflammatory properties of Capsicum baccatum: From traditional use to scientific approach. Journal of Ethnopharmacology, 139(1):228-233. 